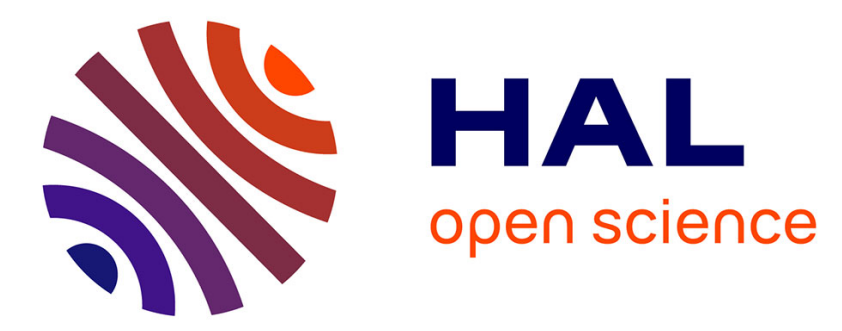

\title{
Seasonal characteristics of the physicochemical properties of North Atlantic marine atmospheric aerosols
}

Y. J. Yoon, D. Ceburnis, F. Cavalli, O. Jourdan, J. P Putaud, M. Facchini, S. Decesari, S. Fuzzi, K. Sellegri, S. G. Jennings, et al.

\section{- To cite this version:}

Y. J. Yoon, D. Ceburnis, F. Cavalli, O. Jourdan, J. P Putaud, et al.. Seasonal characteristics of the physicochemical properties of North Atlantic marine atmospheric aerosols. Journal of Geophysical Research, 2007, 112 (D4), pp.D04206. 10.1029/2005jd007044 . hal-01982563

\section{HAL Id: hal-01982563 https://hal.science/hal-01982563}

Submitted on 15 Jan 2019

HAL is a multi-disciplinary open access archive for the deposit and dissemination of scientific research documents, whether they are published or not. The documents may come from teaching and research institutions in France or abroad, or from public or private research centers.
L'archive ouverte pluridisciplinaire HAL, est destinée au dépôt et à la diffusion de documents scientifiques de niveau recherche, publiés ou non, émanant des établissements d'enseignement et de recherche français ou étrangers, des laboratoires publics ou privés. 


\title{
Seasonal characteristics of the physicochemical properties of North Atlantic marine atmospheric aerosols
}

\author{
Y. J. Yoon, ${ }^{1,2}$ D. Ceburnis, ${ }^{1}$ F. Cavalli, ${ }^{3}$ O. Jourdan, ${ }^{1,4}$ J. P. Putaud ${ }^{5}$ M. C. Facchini, ${ }^{3}$ \\ S. Decesari, ${ }^{3}$ S. Fuzzi, ${ }^{3}$ K. Sellegri, ${ }^{1,4}$ S. G. Jennings, ${ }^{1}$ and C. D. O'Dowd ${ }^{1}$ \\ Received 31 December 2005; revised 24 July 2006; accepted 15 September 2006; published 23 February 2007.
}

[1] Seasonal physicochemical characteristics of North Atlantic marine aerosols are presented for the period from January 2002 to June 2004. The aerosol size distribution modal diameters show seasonal variations, $0.031 \mu \mathrm{m}$ in winter and $0.049 \mu \mathrm{m}$ in summer for the Aitken mode and $0.103 \mu \mathrm{m}$ in winter and $0.177 \mu \mathrm{m}$ in summer for the accumulation mode. The accumulation mode mass also showed a seasonal variation, minimum in winter and maximum in summer. A supermicron sized particle mode was found at $2 \mu \mathrm{m}$ for all seasons showing 30\% higher mass concentration during winter than summer resulting from higher wind speed conditions. Chemical analysis showed that the concentration of sea salt has a seasonal pattern, minimum in summer and maximum in winter because of a dependency of sea-salt load on wind speeds. By contrast, the nonsea-salt (nss) sulphate concentration in fine mode particles exhibited lower values during winter and higher values during midsummer. The water soluble organic carbon (WSOC) and total carbon (TC) analysis also showed a distinctive seasonal pattern. The WSOC concentration during the high biological activity period peaked at $0.2 \mu \mathrm{gC} \mathrm{m}{ }^{-3}$, while it was lower than $0.05 \mu \mathrm{gC} \mathrm{m}{ }^{-3}$ during the low biological activity period. The aerosol light scattering coefficient showed a minimum value of $5.5 \mathrm{Mm}^{-1}$ in August and a maximum of $21 \mathrm{Mm}^{-1}$ in February. This seasonal variation was due to the higher contribution of sea salt in the MBL during North Atlantic winter. By contrast, aerosols during late spring and summer exhibited larger angstrom parameters than winter, indicating a large contribution of the biogenically driven fine or accumulation modes. Seasonal characteristics of North Atlantic marine aerosols suggest an important link between marine aerosols and biological activity through primary production of marine aerosols.

Citation: Yoon, Y. J., et al. (2007), Seasonal characteristics of the physicochemical properties of North Atlantic marine atmospheric aerosols, J. Geophys. Res., 112, D04206, doi:10.1029/2005JD007044.

\section{Introduction}

[2] Aerosols affect the global radiation budget [Houghton et al., 2001], directly through scattering solar radiation [Charlson et al., 1992], and indirectly by characterizing the physical properties of cloud condensation nuclei (CCN) and eventually clouds[Twomey, 1974; Charlson et al., 1987]. Within the global aerosol system, marine aerosols provide one of the most significant contributions to the global radiative budget because of the $70 \%$ ocean surface coverage and the low albedo of the ocean surface. It has

\footnotetext{
${ }^{1}$ Department of Experimental Physics and Environmental Change Institute, National University of Ireland, Galway, Ireland.

${ }^{2}$ Now at Korea Polar Research Institute, Korea Ocean Research and Development Institute, Seoul, South Korea.

${ }^{3}$ Istituto di Scienze dell'Atmosfera e del Clima, Consiglio Nazionale delle Ricerche, Bologna, Italy.

${ }^{4}$ Now at Laboratoire de Météorologie Physique, Université Blaise Pascal/Centre National de la Recherche Scientifique, Aubiere, France.

${ }^{5}$ Environment Institute, Joint Research Centre, European Commission, Ispra, Italy.

Copyright 2007 by the American Geophysical Union. 0148-0227/07/2005JD007044\$09.00
}

been reported that typical clean marine submicron aerosol size distributions are bimodal, with an Aitken mode $(\mathrm{D}<0.1 \mu \mathrm{m})$ and an accumulation mode $(0.1<\mathrm{D}<0.5 \mu \mathrm{m})$ [Fitzgerald, 1991; Hoppel et al., 1989]. The supermicron coarse mode particles ( $\mathrm{D}>1.0 \mu \mathrm{m}$ ) are mainly formed by the bubble bursting process within breaking waves [Blanchard and Woodcock, 1957; O'Dowd et al., 1993], and as a result, the chemical composition of this mode is mainly sea salt. The physical and chemical characteristics of the Aitken and accumulation mode marine aerosols have been an issue during last decades because of their crucial role in the global climate system. Charlson et al. [1987] hypothesized that non-sea-salt (nss) sulphate derived from the dimethylsulphide (DMS) flux from the ocean surface dominates fine mode sized marine aerosols. Recently, field measurements have also demonstrated the sea-salt contribution to this mode in the marine boundary layer (MBL) [O'Dowd et al., 1997; Murphy et al., 1998]. In addition, organic materials are also found in the fine mode marine aerosols [Putaud et al., 2000; Cavalli et al., 2004]. O'Dowd et al. [2004] presented strong evidence for a dominant contribution to the submicron modes from bubble-mediated 
production processes (primary marine aerosol production) and illustrated that the relative contribution of organic matter and sea salt possessed a seasonal cycle over the North Atlantic with peak organic matter contributions occurring during the periods of peak biological activity and peak sea-salt contributions occurring during periods of low biological activity.

[3] The previous work by Cavalli et al. [2004] and O'Dowd et al. [2004] reported sampling and analytical techniques used to quantify the size-segregated chemical composition from a limited set of chemical measurements in clean marine air (i.e., in terms of a shorter observing period and significantly fewer samples collected). One of their conclusions was that the majority of the aerosol mass, both inorganic sea salt and organic matter, was linked to bubblemediated aerosol production and that the organic fraction was linked to organic matter concentrated at the ocean surface resulting from plankton blooms. Despite a limited data set, O'Dowd et al. [2004] revealed clear differences in aerosol chemistry and microphysics during periods of high and low biological activity based on chlorophyll- $a$ concentration in oceanic surface water. However, a more comprehensive evidence of the coexistent seasonal changes of various aerosol properties and processes in the oceanic surface waters has been lacking to explain the differences between the seasons. In this study, we present a more detailed analysis of the seasonal variation in aerosol microphysical, chemical and optical properties in clean marine air and oceanic chlorophyll- $a$ distribution patterns over the period from January 2002 to June 2004.

\section{Sampling and Analysis}

2.1. Measurement Site and Marine Air Mass Condition

[4] A series of instruments to monitor the physical and chemical characteristics of aerosols are deployed at the Mace Head Atmospheric Research Station. The Mace Head Atmospheric Research Station is located on the west coast of Ireland $\left(53^{\circ} 20^{\prime} \mathrm{N}, 9^{\circ} 54^{\prime} \mathrm{W}\right)$, an ideal location to obtain continuous information about marine aerosols of North Atlantic regions because of prevailing westerly-southwesterly winds. Meteorological data from the station show that $52 \%$ of the air mass arriving at Mace Head can be defined as clean North Atlantic marine air (180-300 ${ }^{\circ}$ wind direction sector) [Jennings et al., 2003]. Results from air mass trajectory models usually show that these air masses stayed over the ocean for 4-5 days before arriving at Mace Head. Typical air mass back trajectories for April and June are shown in Figure 1. Black carbon concentration for these marine air cases are smaller than $40 \mathrm{ng} \mathrm{m}^{-3}$, satisfying typical values for marine air [O'Dowd et al., 1993; Cooke et al., 1997].

\subsection{Aerosol Size Distribution}

[5] Aerosol size distributions at Mace Head were continuously measured by deploying a Scanning Mobility Particle Sizer (SMPS). The SMPS system is composed of a Differential Mobility Analyzer (DMA, TSI 3071), a Condensation Particle Counter (CPC, TSI 3010), an aerosol neutralizer (TSI 3077), a control unit, and a data logging system. The scanning time resolution is set to $120 \mathrm{~s}$ for mobility particle diameters from 0.01 to $0.25 \mu \mathrm{m}$. A closed loop for aerosol free sheath and excess air [Jokinen and Makela, 1997] was operated by using a diaphragm pump. The excess air flow for SMPS is $10 \mathrm{l} / \mathrm{min}$ through use of a critical orifice to maintain 10 to 1 ratio against the sample air flow, $11 / \mathrm{min}$. Aerosol was sampled through the laminar flow community air sampling system at Mace Head. This sampling stainless tube has a diameter of $10 \mathrm{~cm}$ and the inlet is $10 \mathrm{~m}$ above the ground.

[6] The SMPS data for the period from January 2002 to June 2004 (30 months) are analyzed in this study to show seasonal characteristics in the aerosol size distribution. Because the SMPS system was operated regardless of the origin of air mass, and since this work was focused on marine air, size distributions were only selected for marine air cases. Criteria for marine air classification are (1) wind direction should be within the $190-300^{\circ}$ sector; (2) black carbon concentration measured by Aethelometer, Model AE-9 (MaGee Scientific), is lower than $40 \mathrm{ng} \mathrm{m}^{-3}$; (3) total particle number concentration above $14 \mathrm{~nm}$ is less than $700 \mathrm{~cm}^{-3}$; and (4) 5 days air mass back trajectories from a model (R. R. Draxler and G. D. Rolph, Silver Spring; http:// www.arl.noaa.gov/ready/hysplit4.html) should show that the air mass stayed only over North Atlantic Ocean before arriving at the station. Coastal particle formation events are observed at Mace Head more than $50 \%$ of days during a year [Yoon et al., 2006]. These nucleated particles can either grow to accumulation mode size in situ if wind speed is low, or disperse under strong wind conditions at Mace Head. Measured aerosol size distributions were selected only for periods which were not affected by particle formation events: during clean marine conditions, nucleation modes may appear at sizes less than $10 \mathrm{~nm}$ during a nucleation event but rarely are observed to grow to sizes larger than $10 \mathrm{~nm}$, as seen in polluted events [O'Dowd et al., 2002a, $2002 \mathrm{~b}$ ]. All data were screened to ensure that for the analysis used in this study, no conditions during which the nucleation mode was present at sizes larger than $10 \mathrm{~nm}$ was used. Lastly, only periods ranging from 12 to 36 hours with stable aerosol size spectra were chosen to satisfy the condition of constant marine air mass characteristics. Aerosol number size distributions satisfying aforementioned conditions were selected carefully and a total of 61 cases of 12 to 36 hours mean aerosol size distributions were obtained from the 30 month continuous SMPS measurements. Such an example of clean and stable marine aerosol conditions for 24 hours is shown in Figure 2.

\subsection{Particle Mass Concentration Distribution}

[7] Particle mass measurements were undertaken using a Micro-Orifice Uniform Deposit Impactor (MOUDI). The MOUDI uses circular jets to separate particles aerodynamically onto ten impaction stages plus an inlet stage within a range of $0.056-18 \mu \mathrm{m}$ (flow rate $1.8 \mathrm{~m}^{3} \mathrm{~h}^{-1}$, equivalent aerodynamic cutoff diameters at $50 \%$ efficiency: 0.056 ; $0.10 ; 0.18 ; 0.32 ; 0.56 ; 1.0 ; 1.8 ; 3.2 ; 5.6 ; 10 ; 18 \mu \mathrm{m})$. The instrument was located in a wooden housing $\left(\sim 2 \mathrm{~m}^{3}\right.$ volume) outside the Mace Head shore laboratory building in order to be as close to the ambient environment as possible. The MOUDI impactor could not be placed outside as it cannot be properly protected from strong winds and precipitation at the coast. The housing was approximately $80 \mathrm{~m}$ from the coastline during high tide. The inlet of the MOUDI was about $2 \mathrm{~m}$ above ground. The MOUDI was 

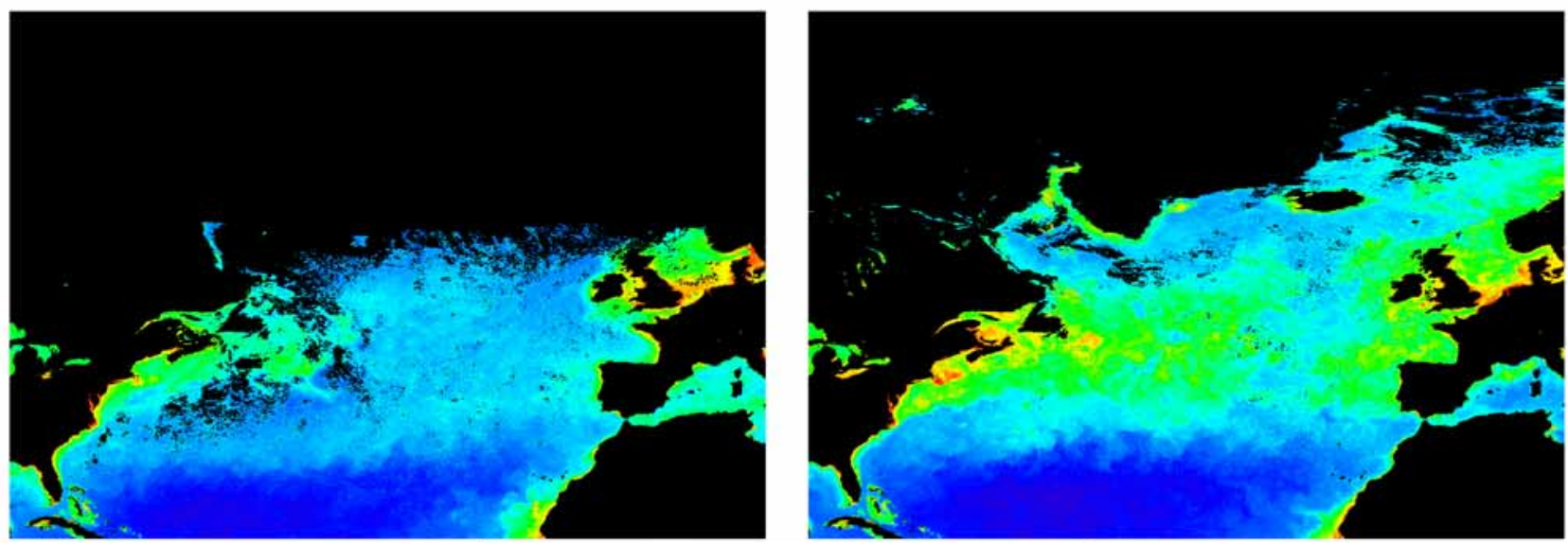

a) February

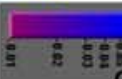

Chlorophull a Concentration $\left(\mathrm{mg} / \mathrm{m}^{3}\right)$ \&

b) April

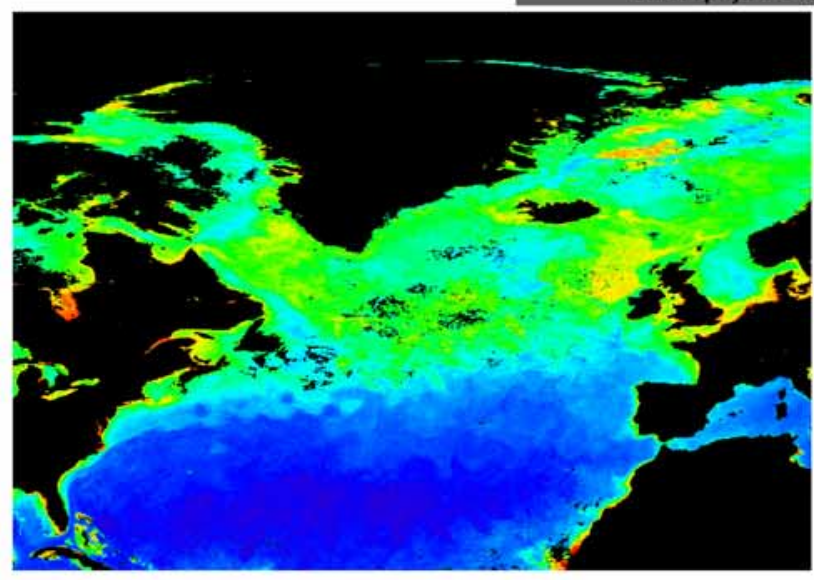

c) June

NOAA HYSPLIT MODEL Backward trajectories ending at 12 UTC 26 Apr 04

FNL Meteorological Data

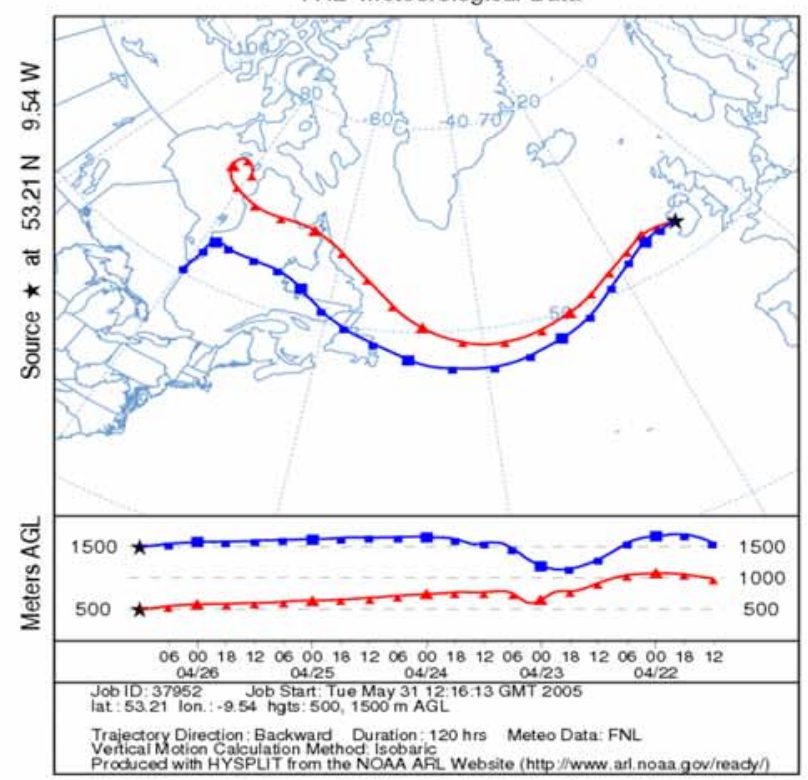

e)

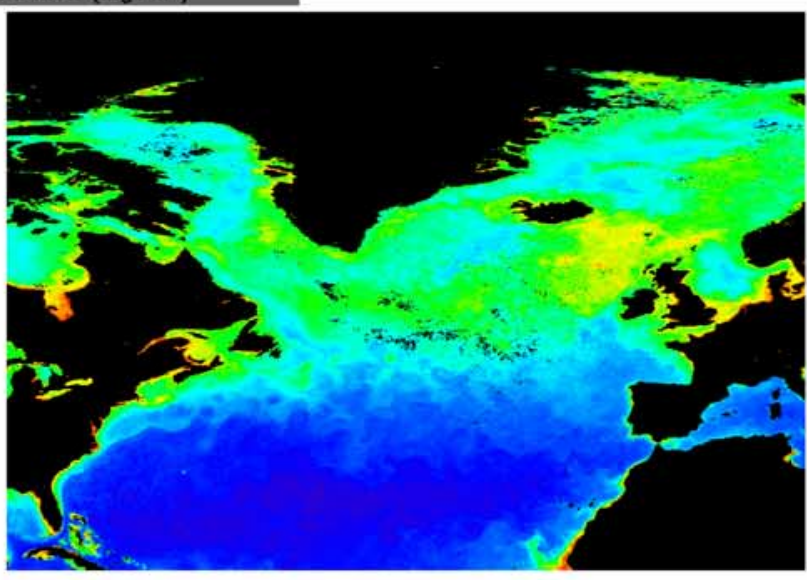

d) August

NOAA HYSPLIT MODEL Backward trajectories ending at 12 UTC 13 Jun 04 FNL Meteorological Data

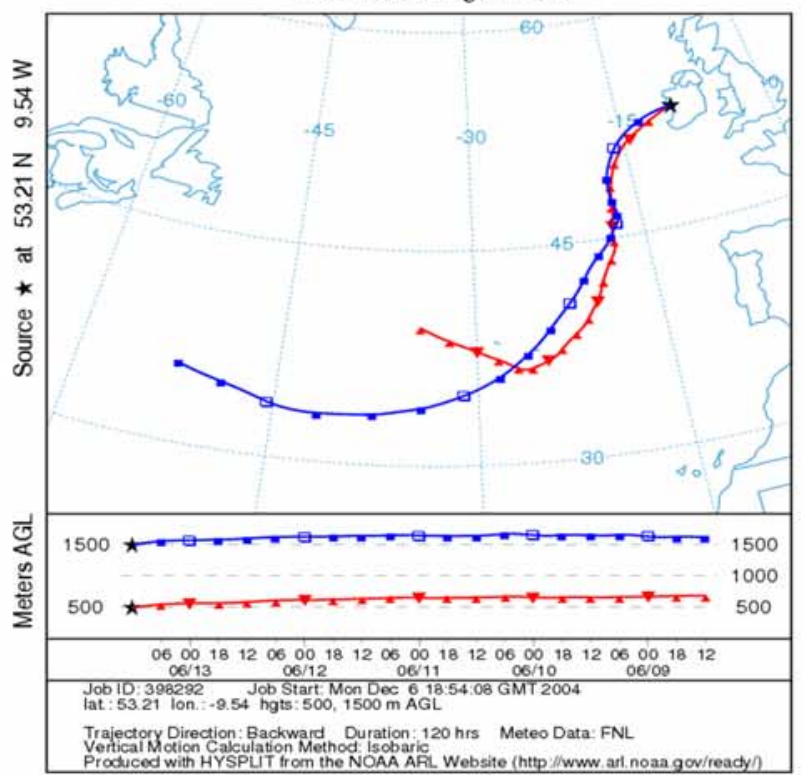

f)

Figure 1. Monthly averages of chlorophyll- $a$ concentration (from SeaWiFS) over the North Atlantic for (a) February, (b) April, (c) June, and (d) August 2004 and typical clean marine air mass back trajectories for (e) April 2004 and (f) June 2004. 
(a)
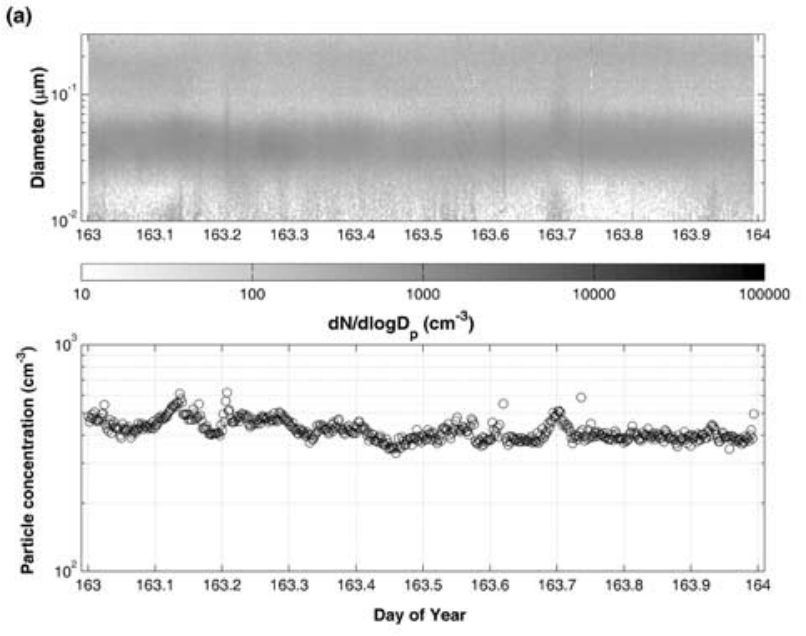

(b)

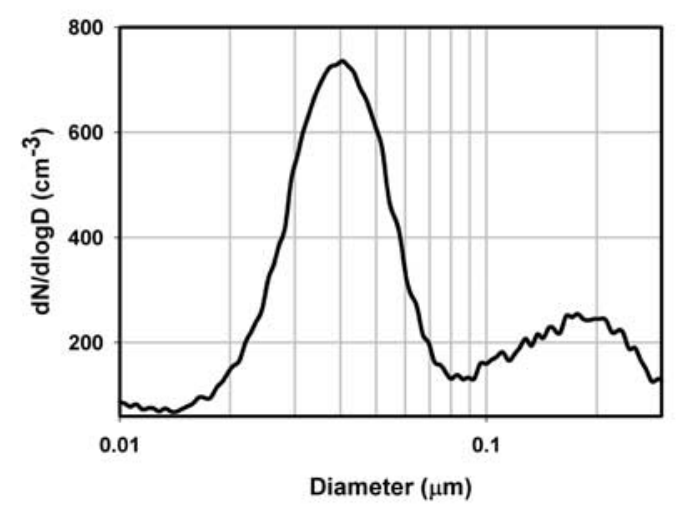

Figure 2. A typical aerosol size distribution measured by the SMPS system at the Mace Head Atmospheric Research station for a very clean marine air case: (11 June 2004, day of year (DOY) 163). (a) Surface plot of the size distribution and the total particle number concentration derived from the SMPS and (b) daily averaged aerosol size distribution.

operated by a computer controlled system, which allowed sampling only when the criteria of clean marine air were met. The MOUDI sample was one week long in order to collect sufficient particulate matter to make accurate gravimetric analysis, especially regarding accumulation mode mass. However, the actual number of hours varied and was dependent on clean sector conditions. The MOUDI impactor was mounted with $\mathrm{Al}$ foils, which were preconditioned for 24 hours at $35-40 \%$ relative humidity and $20^{\circ} \mathrm{C}$ and weighed with a Mettler Toledo microbalance $(1 \mu \mathrm{g}$ sensitivity). After sampling, the $\mathrm{Al}$ foils were conditioned again for 24 hours and weighed. 23 weekly samples were obtained at Mace Head over the period of 2002-2004. Although a histogram is a more appropriate way to present cascade impactor spectra, the MOUDI mass-weighted distribution spectrum was presented as a curve instead, in order to reveal a seasonal difference in spectra. The MOUDI mass spectrum was divided into fine and coarse modes (refer to Figure 6), which shows a clear distinction between fine and coarse modes at $1.0 \mu \mathrm{m}$ in diameter. The first five stages, covering $0.056-1.0 \mu \mathrm{m}$ diameter range, were attributed to a fine particle mode, while the remaining five stages were attributed to the coarse fraction. Seasonal variation in accumulation or fine particle mode was calculated by summing concentrations of the first five stages. A standard deviation $(\sigma)$ of the monthly average concentration was presented only for those months, which contained more than one sample.

\subsection{Particle Chemical Composition and Total Carbon Data}

[8] Particle chemical composition and total carbon data were obtained from the samples collected when air masses met clean marine air conditions as already described above. The automated sampling system was used to control the aerosol sampling and each sample was deployed for a period of 7 days. More sampling details are given by Cavalli et al. [2004]. The samples included in this study comprise an extended set of samples collected over the 2002-2004 year period, and which covered more extensively all seasons.

[9] A Berner low-pressure impactor (flow rate $1.8 \mathrm{~m}^{3} \mathrm{~h}^{-1}$ ) was used to collect aerosol particles in eight size fractions, with the following $50 \%$ equivalent aerodynamic cutoff diameters: $0.063 ; 0.125 ; 0.25 ; 0.5 ; 1 ; 2 ; 4 ; 8 ; 16 \mu \mathrm{m}$. Tedlar foils were used as the collection substrate in the impaction stages. The impactor was mounted outside, near the Laboratory shore building at approximately $80 \mathrm{~m}$ from the shoreline at high tide and at a height of approximately $3 \mathrm{~m}$ above ground level. The BERNER chemical species spectrum was divided into fine and coarse modes at $1.0 \mu \mathrm{m}$ particle size. The first four stages, covering $0.060-1.0 \mu \mathrm{m}$ diameter range, were attributed to a fine particle fraction, while the remaining four stages were attributed to the coarse fraction. Seasonal variation in accumulation or fine particle mode was calculated by summing concentrations of the first four stages. A standard deviation of the monthly average concentration was presented only for those months, which contained more than one sample.

[10] Berner tedlar foil water extracts were used to determine the mass weighted distribution of inorganic ions and water-soluble organic carbon (WSOC) content by ion chromatography and a total organic carbon (TOC) liquid analyzer, respectively. A detailed description of the analytical procedure can be found elsewhere [Matta et al., 2003; Cavalli et al., 2004].

[11] Total and water-soluble organic carbon was analyzed in samples collected on quartz fiber filters, using a SierraAndersen high-volume cascade impactor (flow rate $60 \mathrm{~m}^{3} \mathrm{~h}^{-1}$ ), located at ground level $70 \mathrm{~m}$ from the shoreline at high tide. Hi-vol quartz filters were combined into a fine $\left(\mathrm{D}_{50}<1.5 \mu \mathrm{m}\right)$ and a coarse $\left(\mathrm{D}_{50}>1.5 \mu \mathrm{m}\right)$ aerosol fraction and analyzed by a thermal evolved gas analysis (EGA) [Putaud et al., 2000] and WSOC by TOC analysis.

\subsection{Aerosol Scattering}

[12] Aerosol particle optical properties measurements were performed by a TSI Inc. 3563 three-wavelength integrating nephelometer [Bodhaine et al., 1991; Heintzenberg and Charlson, 1996]. This instrument is designed to measured aerosol light scattering coefficient with a sampling frequency of $1 \mathrm{~Hz}$ at 3 wavelengths (450, 550 and $700 \mathrm{~nm}$ ) with two ranges of angular integration: 
$\left(7-170^{\circ}\right)$ to determine the total scattering coefficient $\sigma_{s p}$ and $90-170^{\circ}$ for the assessment of hemispheric backscattering.

[13] The nephelometer was also connected via the community air-sampling system with a flow rate of $150 \mathrm{l} / \mathrm{min}$ to ensure laminar flow. The instrument was regularly calibrated using $\mathrm{CO}_{2}$ and particle free air during the 30-month period of measurements. Moreover, an automatic zero calibration with particle free air was performed every $60 \mathrm{~min}$ for setting the instrument zero. The instrument noise is assessed as the standard deviation of the zero baseline measurements in order to determine the detection limit of the nephelometer. The mean detection limit of the nephelometer amounts to $0.3 \mathrm{Mm}^{-1}$ as defined by a signal-tonoise ratio of 2. A detailed discussion of the performance characteristics of this commercial instrument is also given by Anderson et al. [1996].

[14] Because of internal heating of the nephelometer, aerosols were sampled at an average relative humidity of $35 \pm 5 \%$. It should be noted that light scattering measurements are dependent upon the relative humidity (RH) since scattering increases as a function of size. However, if the particles are maintained at RHs of $10-40 \%$ this variation is minimized [see Anderson and Ogren, 1998] and the particles can be approximated as dry from a scattering point of view. Therefore, even though the sampled aerosols are not chemically dry the derived optical properties from the nephelometer measurements should be considered as representing dry aerosol particles only.

[15] Another crucial point that must be addressed concerns the underestimation of the aerosol light scattering coefficient due to submicrometer and supermicrometer particles losses in the sampling system. Indeed, the loss of particles are mainly caused by inertial deposition in the near $90^{\circ}$ bend of the sampling line as well as in the flow constriction at the nephelometer duct. In this respect, the total efficiency (product of the transport efficiency by the inlet efficiency) was calculated by Kleefeld et al. [2002] for the Mace Head nephelometer sampling system. They found that the $50 \%$ cutoff diameter of the system was about $8 \mu \mathrm{m}$ at low wind speed conditions $\left(5 \mathrm{~m} \mathrm{~s}^{-1}\right)$ and decreased to $2 \mu \mathrm{m}$ at wind speeds of $15 \mathrm{~m} \mathrm{~s}^{-1}$; and that for wind speeds lower than $10 \mathrm{~m} \mathrm{~s}^{-1}$ up to $20 \%$ of the submicrometer fraction of the size spectrum particles was removed from the sampling volume. Finally they showed that, although the nephelometer measurements in Mace Head underestimated the light scattering, the measured scattering coefficients were in good agreement with the results of similar measurements in the marine boundary layer. Therefore, for moderate wind speed (4-12 $\mathrm{m} \mathrm{s}^{-1}$ ), the sampling characteristics of the nephelometer inlet was similar to the performance of the nominal usually used $10 \mu \mathrm{m}$ cutoff inlets.

[16] Scattering coefficients at three wavelengths were recorded with a temporal resolution of $5 \mathrm{~min}$ during a 30-month period from January 2002 to June 2004 in presence of marine air masses as defined earlier. An offset was then routinely performed as well as an intercomparison with a one-wavelength nephelometer $(550 \mathrm{~nm})$ positioned next to the three-wavelength model. The data were then integrated to hourly mean scattering coefficients in order to smooth out the light scattering signal. Wind corrections were also applied to the scattering data set using a simple threshold technique when the measured wind speed presented abnor- mal high or low values for a particular day. This step enabled us to obtain scattering coefficients measurements that are not biased by excessively large submicrometer and supermicrometer particles losses in the sampling system. A total of 48 cases of scattering data are analyzed for the period from January 2002 to June 2004 (30 months), which satisfies the marine air mass conditions. Usually, the wind speed is higher in winter than in fall, spring and summer. Accordingly, some cases were not considered during summer and spring when abnormally high wind speeds were encountered.

[17] Finally, in order to make a better characterization of aerosol optical properties, we also calculated an hourly mean Angström exponent $\alpha$ derived from a multispectral $\log$ linear fit of the equation $\sigma_{\mathrm{sp}} \sim \lambda^{-\alpha}$ (based on the three nephelometer wavelengths), where $\sigma_{\mathrm{sp}}$ is the aerosol scattering coefficient and $\lambda$ is the wavelength. It is important to note that the Angström exponent characterizes part of the intensive properties (independent of concentration) of aerosol particles whereas $\sigma_{\mathrm{sp}}$ mostly describes their extensive properties (dependent on concentration) and their supermicrometer fraction [Ogren, 1995]. Although the Angström exponent is usually assessed using the optical depth instead of the scattering coefficient, it can still be considered as a first-order parameter indicative of the general size distribution and the presence of fine or coarse mode aerosols (for examples, refer to Smirnov et al. [2002] and Öström and Noone [2000]).

\subsection{Chlorophyll- $\boldsymbol{a}$ Measurements}

[18] The Sea-viewing Wide Field-of-view Sensor (SeaWiFS) satellite is used in this study to provide quantitative data on ocean bio-optical properties. Subtle changes in ocean color signify various types and quantities of marine phytoplankton (microscopic marine plants). The color in most of the world's oceans in the visible light region, (wavelengths of 400-700 nm) varies with the concentration of chlorophyll and other plant pigments present in the water; that is, the more phytoplankton present, the greater the concentration of plant pigments and the greener the water. Thus the SeaWiFS chlorophyll- $a$ product is chosen as an indicator of biological activity over the northeast Atlantic. The products used are level 2 products taken from the SeaWiFS home page (http:// oceancolor.gsfc.nasa.gov/SeaWiFS/).

\section{Results}

\subsection{Chlorophyll-a Distributions}

[19] The concentration of chlorophyll- $a$, which represents a proxy of phytoplankton biomass (i.e., primary organic matter) at the ocean surface, show a clear seasonal pattern (Figure 1). Land areas and areas of no coverage or cloud blockage are indicated in black. During winter months of December and January, chlorophyll- $a$ concentrations in the surface waters displayed the lowest values, about $0.2 \mathrm{mg} \mathrm{m}^{-3}$, with a pattern fairly uniform across all the North Atlantic open-sea region, with slightly elevated concentrations along the coastline. The phytoplankton bloom started in early spring during late February and March along the coastline, but was mainly localized in patches of increasing concentrations still within the continental shelf. For instance, in 2004 the bloom started around Newfoundland, 


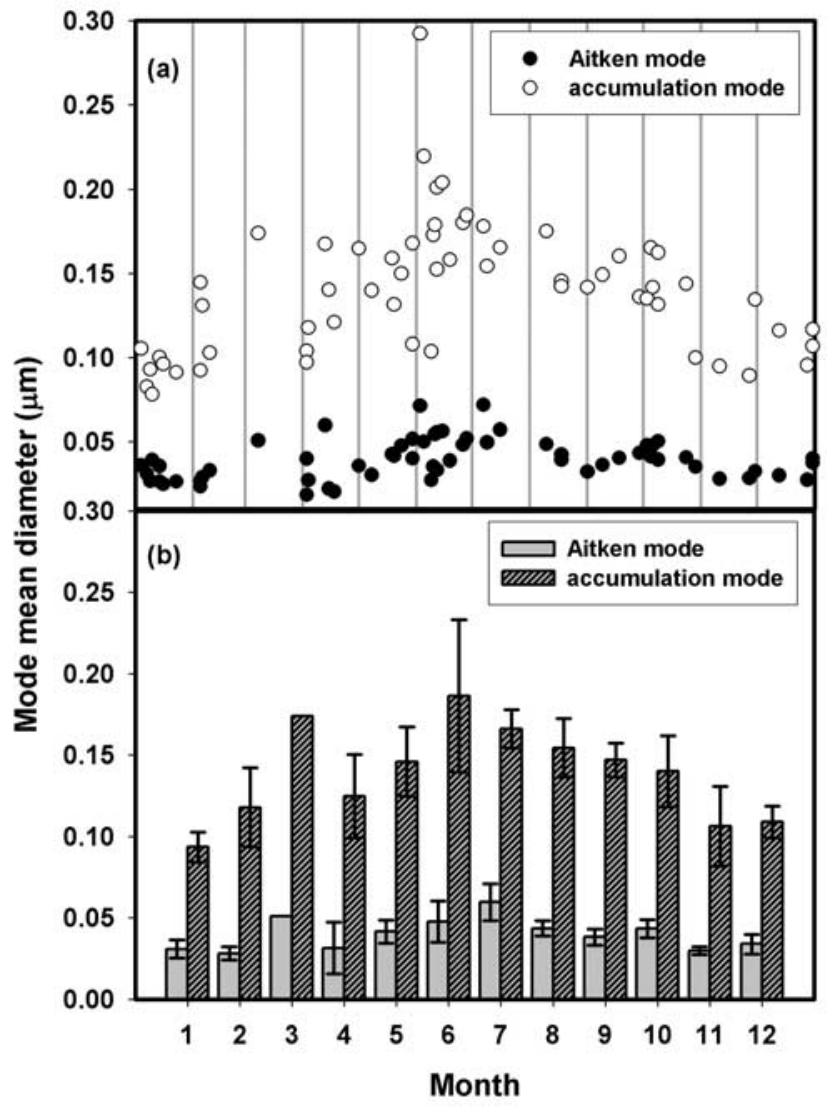

Figure 3. Monthly variations of lognormal aerosol size distribution mode mean diameters for the Aitken and the accumulation modes and the error bars correspond to the standard deviations $(\sigma)$. (a) Individual data points and (b) monthly averages. Data are presented from January 2002 to June 2004 (month 1 is the January average over the reported period).

along the Portuguese coast, Bay of Biscay and in the North Sea. Chlorophyll- $a$ reaches concentrations as high as $1.0 \mathrm{mg} \mathrm{m}^{-3}$ in these patches. In April and May, the bloom gradually spreads to the open ocean westward and eastward from opposite coasts of Atlantic ocean until it occupies the entire North Atlantic above 35th latitude north while chlorophyll- $a$ concentration reaches its maximum average value at about $2.0 \mathrm{mg} \mathrm{m}^{-3}$ during the month of May. During May-June the southern boundary of the bloom moves slowly toward the north for about $1000 \mathrm{~km}$ until it reaches $45^{\circ}$ latitude north and stays there for the rest of the summer period. Chlorophyll- $a$ concentration is as high as during the April-May period. After the bloom has moved toward the north it leaves surface waters of the area between $45^{\circ}$ and $35^{\circ}$ latitudes rather depleted in chlorophyll but not completely depleted of biomass. During summer, the bloom does not show any significant changes, with the exception of high chlorophyll concentration patches mainly in the region between Scotland and Iceland. Chlorophyll- $a$ concentration can reach $3 \mathrm{mg} \mathrm{m}^{-3}$ or more. During August-September, the southern boundary of the bloom is gradually shifted back south bellow $45^{\circ}$ latitude, with gradually lower concentrations above $60^{\circ}$ latitude.
During October and November, the bloom is rapidly fading from central parts of the North Atlantic toward the continental shelf and further toward the coastlines. Concentrations remain at their lowest during December and January and then the cycle starts over again.

[20] Primary aerosols produced over biologically active waters can be enriched in organic matter, however, the enrichment factor may depend on air mass trajectory patterns. Air mass trajectories exhibited slightly different pattern depending on the season. During winter, spring and autumn air mass backward trajectories follow more or less the trans-Atlantic route as depicted in Figure 1. During summer months and especially during June and July, trajectories tend to originate in the mid-Atlantic, and therefore pass at least partly over chlorophyll depleted waters (Figure 1). However, such a partial path over depleted region is not the general rule, but rather southern trajectories are more frequent. A more comprehensive description of the air mass trajectories during the biologically active season have already been presented by Cavalli et al. [2004]. These chlorophyll data are presented to indicated the seasonal variation in oceanic biological activity over which air mass back trajectories advect.

\subsection{Seasonality in Aerosol Size Distribution}

[21] A typical 24-hour stable aerosol size distribution for a very clean air mass case used in the results presented is shown in Figure 2. This example shows the SMPS data measured for 24 hours on 11 June 2004 (day of year (DOY) 163). The concentration of black carbon was lower than $30 \mathrm{ng} \mathrm{m}^{-3}$ during the day. Wind direction was westerly with a wind speed of $9-11 \mathrm{~m} \mathrm{~s}^{-1}$ on that day. The 5 days back trajectory map shows that air mass were transported from North Atlantic to Mace Head spending all 5 days over the ocean. The total aerosol number concentration derived from the SMPS measurement for clean marine air mass cases is typically $300-500 \mathrm{~cm}^{-3}$. It is clear from Figure 2 that there are two aerosol size modes, around $40 \mathrm{~nm}$ for the Aitken mode and around $180 \mathrm{~nm}$ for the accumulation mode (see Figure $2 \mathrm{~b}$ ). The locations of these modes do not change over the 24 hours because of the steady wind direction and air mass back trajectory.

[22] According to the definitions in this study used for very clean North Atlantic Ocean air mass arriving at Mace Head, a total of 61 cases of stable SMPS data for very clean North Atlantic Ocean air masses (using the criteria in section 2.2) were processed to determine lognormally fitted modal values, such as mean diameter, standard deviation, and modal number concentration. Figure 3 shows the modal diameter for each case (Figure 3a) and monthly averaged values (Figure 3b), respectively. It should be noted that there is only one case for March and it was not possible to calculate a standard deviation for this month. The modal mean diameter shows a clear monthly variation, particularly for the accumulation mode. The maximum mean accumulation mode diameter of $0.186 \pm 0.047 \mu \mathrm{m}$ is found in June, with a minimum of $0.093 \pm 0.009 \mu \mathrm{m}$ in January. For the Aitken mode, the maximum diameter of $0.060 \pm 0.011 \mu \mathrm{m}$ is found in July and a minimum value of $0.028 \pm 0.004 \mu \mathrm{m}$ in February. The ratio between the maximum and minimum diameter is about 2 for both modes, which results in a factor of 4 and 8 increase in aerosol total surface area and volume, 


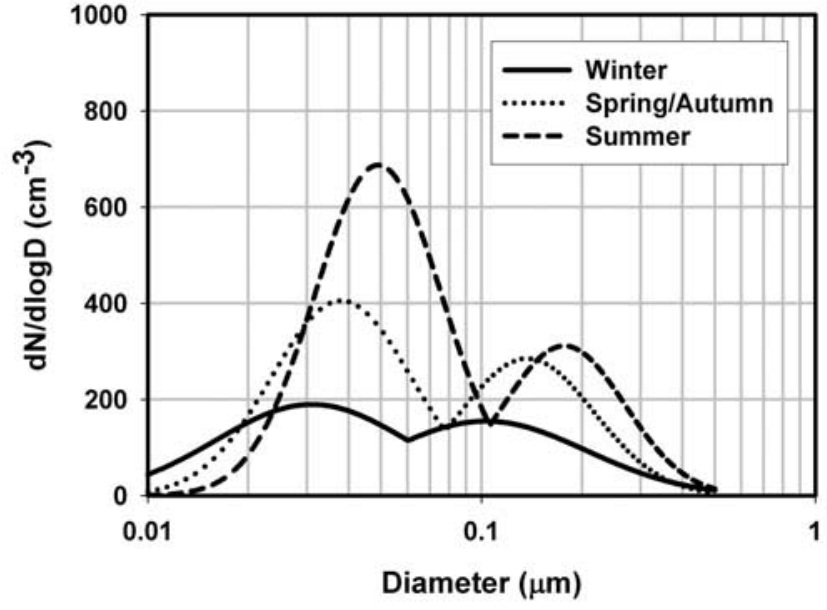

Figure 4. Seasonal lognormally fitted aerosol size distributions over the period from January 2002 to June 2004.

respectively. It was found that the Aitken mode concentration also shows a seasonal pattern, with a minimum for winter time and a maximum for summer. Accumulation mode number concentration show minimum values during winter time and larger values for the rest of the seasons.

[23] Seasonally averaged lognormally fitted values for aerosol size distributions were derived for the 61 cases covering the 30 months period. In this analysis, summer represents June-July-August; and winter represents December-January-February. These seasonal modal diameters along with standard deviations and number concentrations are listed in Table 1 and in Figure 4, and show typical aerosol log normal size distribution parameters from the calculated seasonal values. It is clear that modal diameters
Table 1. Seasonal Aerosol Size Distribution Lognormal Fitting Parameters for the Aitken Mode and the Accumulation Modes ${ }^{\mathrm{a}}$

\begin{tabular}{lccccccc}
\hline & \multicolumn{3}{c}{ Aitken Mode } & & \multicolumn{3}{c}{ Accumulation Mode } \\
\cline { 2 - 4 } \cline { 7 - 8 } & $\mathrm{D}_{\mathrm{g}}$ & $\sigma$ & $\mathrm{N}$ & & $\mathrm{D}_{\mathrm{g}}$ & $\sigma$ & $\mathrm{N}$ \\
\hline Winter & 0.031 & 1.942 & 137.242 & & 0.103 & 2.000 & 116.690 \\
Spring/autumn & 0.038 & 1.623 & 213.346 & & 0.137 & 1.592 & 144.755 \\
Summer & 0.049 & 1.551 & 327.520 & & 0.177 & 1.517 & 142.354 \\
\hline
\end{tabular}

${ }^{\mathrm{a}} \mathrm{D}_{\mathrm{g}}$, geometric mean diameter in $\mu \mathrm{m} ; \sigma$, standard deviation; and $\mathrm{N}$, number concentration in $\mathrm{cm}^{-3}$.

for summer are larger (by around 40\%) than the values for winter for both Aitken and accumulation modes. The spring and summer seasons show intermediate values.

\subsection{Seasonality in Aerosol Mass Concentration}

[24] Figure 5 shows size segregated aerosol mass distributions measured by a MOUDI impactor. During winter time, an accumulation mode is almost nonexistent while during the period of spring to autumn there is a distinctive accumulation mode at about $0.4 \mu \mathrm{m}$ in diameter. A supermicron particle mode is present at $2 \mu \mathrm{m}$, irrespective of season. Previous studies [O'Dowd et al., 2004; Cavalli et al., 2004] have shown that apart from a clear difference in size between the modes at about $1 \mu \mathrm{m}$ in diameter there is a distinct difference in chemical composition of the modes. It should be noted that the supermicron mode needs to be considered carefully, because it is truncated above $5 \mu \mathrm{m}$. Truncation of the mass spectrum is caused by the MOUDI inlet sampling efficiency. A study by Howell et al. [1998] showed that at $5 \mathrm{~m} \mathrm{~s}^{-1}$ wind speed the MOUDI exhibited a $\mathrm{D}_{50}$ cutoff diameter of $7 \mu \mathrm{m}$. The average wind speed at Mace Head was 5 to $9 \mathrm{~m} \mathrm{~s}^{-1}$ in clean marine air masses, and

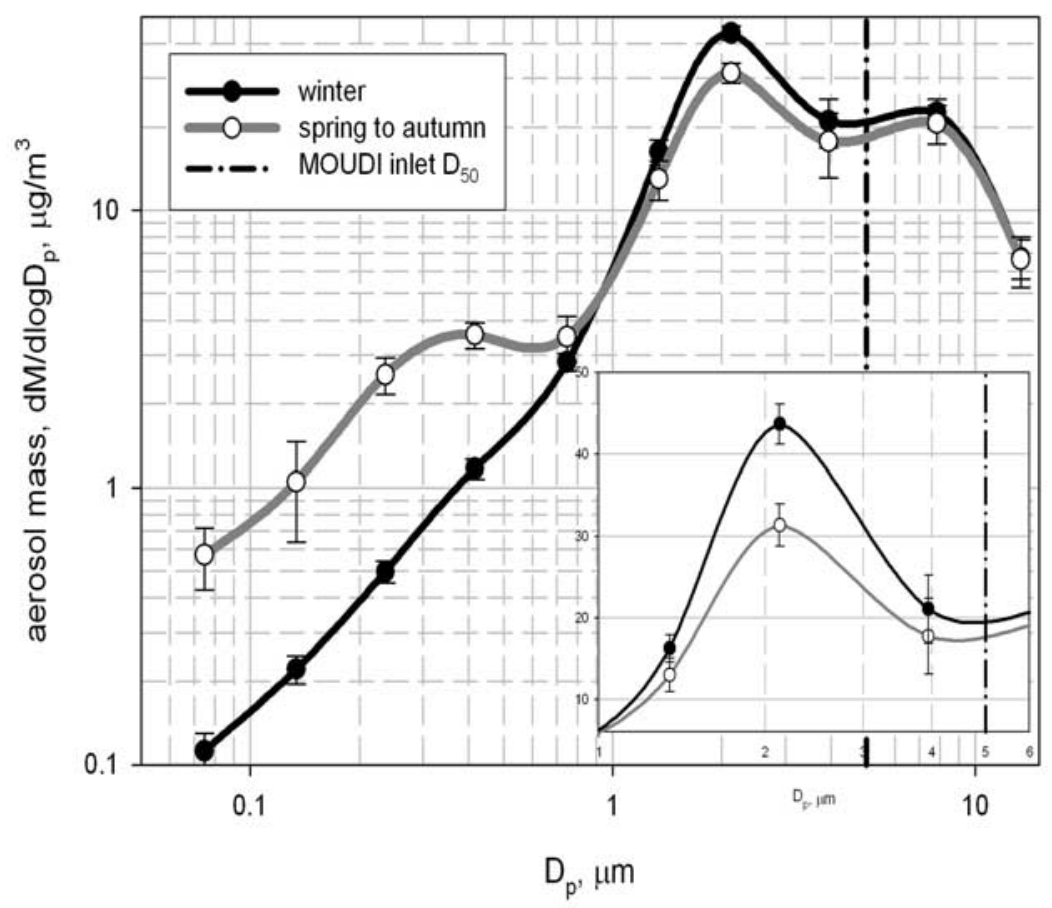

Figure 5. Seasonal differences in aerosol mass size distribution spectra measured by the MOUDI impactor in clean marine air. The MOUDI $D_{50}$ inlet efficiency is estimated for a wind speed of $7 \mathrm{~m} \mathrm{~s}^{-1}$ to be $5 \mu \mathrm{m}$. Insert graph is to highlight aerosol mass distribution between 1 and $6 \mu \mathrm{m}$ with a linear $y$ axis scale. 


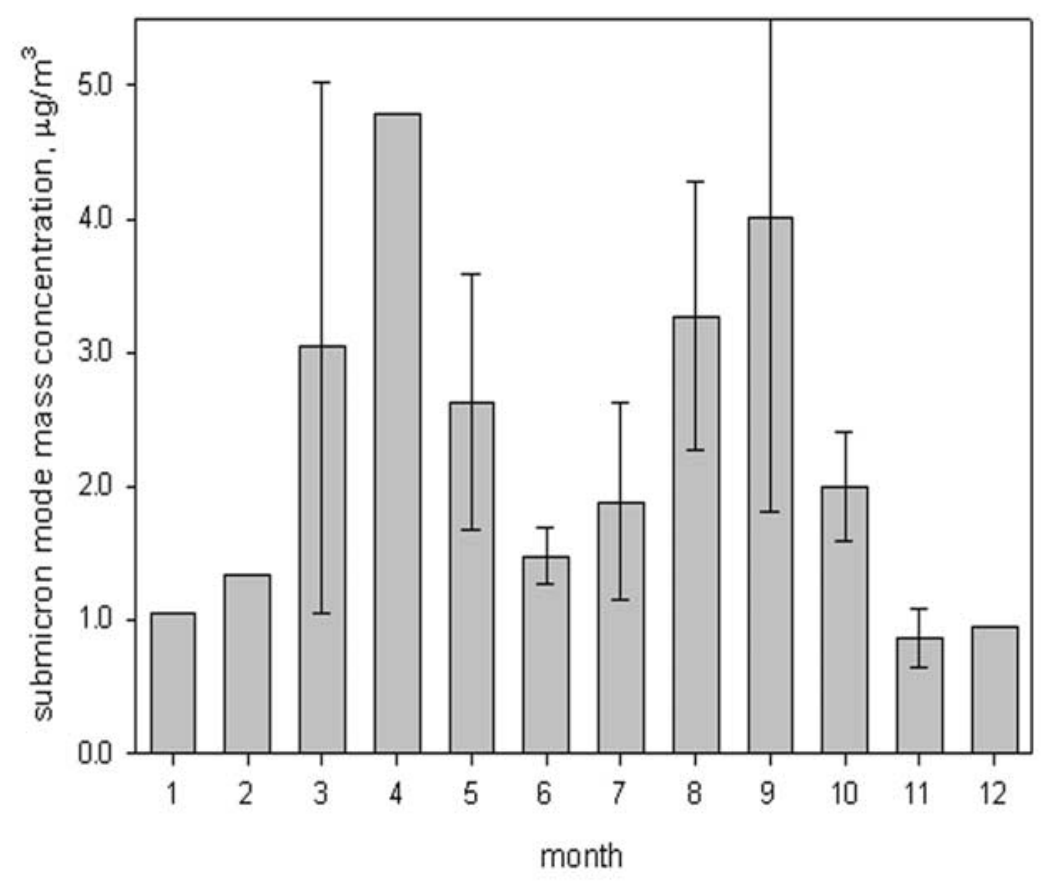

Figure 6. Seasonal variation in accumulation mode mass concentration over the period from January 2002 to June 2004, averaged per month. The figure shows average monthly concentration $\pm 1 \sigma$ (except for months with a single value).

therefore it is estimated that the $\mathrm{D}_{50}$ diameter was close to $5 \mu \mathrm{m}$ at a wind speed of about $7 \mathrm{~m} \mathrm{~s}^{-1}$. Seasonal variation in accumulation mode mass is presented in Figure 6 where clear differences are seen between the seasons. Minimum submicron mass concentrations were observed from November to February, and during June and July while maximum mass concentrations were observed during April and September.

[25] The seasonal variation of supermicron particle mass is less prominent mainly because of its short lifetime relative to the submicron particles and also because it is likely to have more surf-zone interference. Nevertheless, supermicron particle mass was at least on average $30 \%$ higher during winter, as highlighted in the insert of Figure 5 which has a linear $y$ axis scale. This is attributed to the typical difference in wind speeds between winter and summer periods with the higher wind speeds occurring in winter.

\subsection{Seasonality in Aerosol Chemical Composition}

[26] Size resolved chemical composition data were divided into fine and coarse fractions and seasonal patterns were investigated. Berner impactor samples were divided into fine $(0.060-1.0 \mu \mathrm{m})$ and coarse $(1.0-16.0 \mu \mathrm{m})$ fractions which included four stages for each mode. The hi-vol Sierra Andersen impactor samples were divided into a fine fraction which contained particles smaller than $1.5 \mu \mathrm{m}$ in diameter and that collected on a backup filter, and a coarse fraction which contained particles in the $1.5-10 \mu \mathrm{m}$ range. Only the fine fraction of selected chemical species is presented in Figures 7-11, while coarse fraction patterns are discussed for selected cases. Each figure contains a yearly time series together with a monthly average with standard deviation, which shows the seasonal variability.
[27] Figure 7a shows the temporal variability of submicron sea-salt aerosol for the period from January 2002 to June 2004. Monthly averaged concentration of submicron sea salt is presented in Figure $7 \mathrm{~b}$ which shows a minimum in summer and a maximum in winter. A similar pattern, but somewhat spikier is found for the sea-salt coarse fraction. Sea-salt content in atmospheric aerosol particles is related to the wind speed by an exponential relationship [e.g., Fitzgerald, 1991; O'Dowd et al., 1997, and references therein]. Wind speed over the North Atlantic is consistently higher during the winter season, thus causing a higher seasalt aerosol loading.

[28] The data for nss $\mathrm{SO}_{4}$ and methanesulfonate (MSA) concentrations showed a seasonal pattern with low concentrations during winter and maximum concentrations during midsummer (Figures 8 and 9), which is opposite to that obtained for sea salt. Note that there was a lower limit of detection for measurement of MSA concentration $\left(\sim 0.005 \mu \mathrm{g} \mathrm{m}^{-3}\right)$ because of a combination of an analytical detection limit and low particulate mass due to clean sector sampling conditions and size discrimination of samples. Therefore Figure 9 does not contain winter MSA data. Such a pattern along with highly correlated fine mode MSA mass concentration (Figure 10$)(\mathrm{r}=0.84, \mathrm{P} \ll 0.01)$ with nss $\mathrm{SO}_{4}$ fine mode mass concentration suggests a biogenic source. The ratio between fine aerosol mode nss $\mathrm{SO}_{4}$ and MSA for spring and summer season was calculated as 3.87, which is in good agreement with Savoie et al. [2002], who report ratios between 2.59 and 3.92 for the summer season biogenic nss $\mathrm{SO}_{4}$. However, Savoie et al. [2002] did not discriminate between fine and coarse aerosol modes (which were total suspended particulate samples), used different criteria for air masses of marine origin $\left({ }^{210} \mathrm{~Pb}\right.$ concentration) and applied a tracer method for regression analysis ( $\mathrm{Sb}$ or 


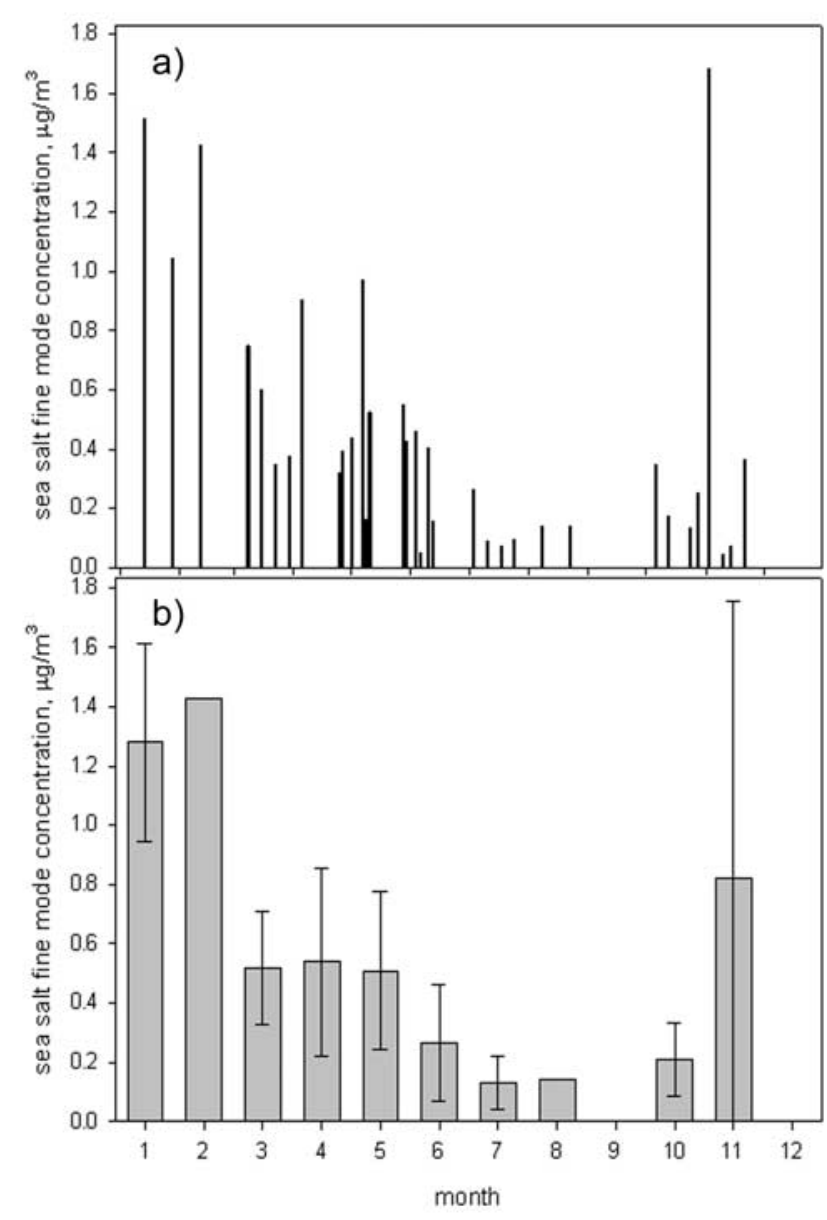

Figure 7. Variation of submicron sea-salt concentration: (a) Time series of fine mode $(<1.5 \mu \mathrm{m}$ diameter $)$ sea-salt mass concentration for individual samples analyzed. (b) Average monthly concentration of fine mode sea-salt mass concentration $\pm 1 \sigma$ (except for months with a single value). Data are presented from January 2002 to June 2004 (month 1 is January).

$\mathrm{NO}_{3}^{-}$). It is worth noting that about 25 to $30 \%$ of MSA was present in coarse particles in our samples. Regression analysis shows that the intercept of nss $\mathrm{SO}_{4}$ concentration is $0.167 \mu \mathrm{g} \mathrm{m}^{-3}$. It can probably be attributed to a footprint of anthropogenic sulphate or the inflow of biogenic nss $\mathrm{SO}_{4}$ from the Southern Hemisphere or both. It is worth noting that the highest nss $\mathrm{SO}_{4}$ concentrations were recorded during late June-July months. During those months, air mass back trajectories were passing over more southerly regions of the North Atlantic, which actually showed a somewhat lower primary biomass with lower chlorophyll- $a$ concentrations in oceanic surface waters. The highest nss $\mathrm{SO}_{4}$ concentration of $0.80 \mu \mathrm{g} \mathrm{m}^{-3}$ (10-17 July 2004) could be attributed to anthropogenic sources, although the air mass characteristics did meet the clean air criteria. The high MSA concentration of $0.15 \mu \mathrm{g} \mathrm{m}^{-3}$ supported by air mass back trajectories of an open ocean origin tends to support the classification of clean air for this case, however, it must be acknowledged that polluted air, with high NOx concentrations, mixing with clean air rich in DMS can also produce high values of MSA [Yin et al., 1990a, 1990b]. Fine $\mathrm{NH}_{4}$ and coarse $\mathrm{NO}_{3}$ concentrations showed similar seasonal patterns to that of nss $\mathrm{SO}_{4}$ pointing to a biogenic source as well, but overall their concentrations were very low as already reported by Cavalli et al. [2004].

[29] A seasonal pattern of water-soluble organic carbon in fine particulate matter is presented in Figure 11. Watersoluble organic carbon was analyzed from Tedlar foils in Berner impactor samples as well as in Hi-vol samples in order to check consistency of the chemical analysis and potential sampling artefacts. There is a general consensus that prefired quartz filters (used in the Hi-vol impactor) may adsorb some volatile organic species causing a positive artefact, while samples on tedlar foils (used in the Berner impactor) are considered to suffer from a negative artefact. However, our data show that WSOC average concentration was $0.103 \mu \mathrm{gC} \mathrm{m}^{-3}$ and $0.120 \mu \mathrm{gC} \mathrm{m}{ }^{-3}$ for Berner and Hi-vol samples, respectively. The correlation coefficient between the two sample sets was $0.76(\mathrm{P} \ll 0.01)$. Therefore it is plausible that sampling artefacts were not likely to significantly bias the results. Figure 11 shows a clear seasonal pattern of WSOC with lowest concentrations during winter and highest during spring-to-autumn. The result confirms the findings of $O$ 'Dowd et al. [2004] which

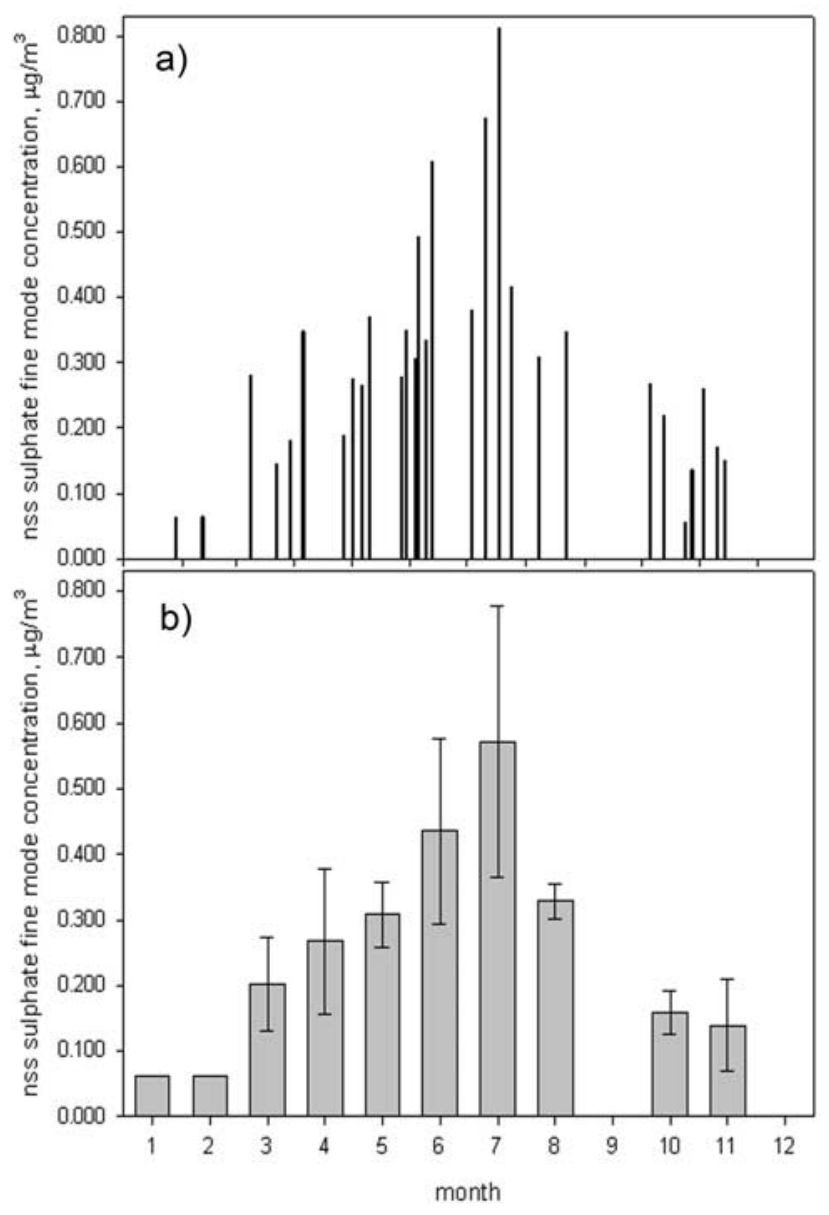

Figure 8. Seasonal variation of the submicron nss $\mathrm{SO}_{4}$ concentration. (a) A time series of individual samples analyzed. (b) Average monthly concentration $\pm 1 \sigma$ (except for months with a single value). Data are presented from January 2002 to June 2004 (month 1 is January). 


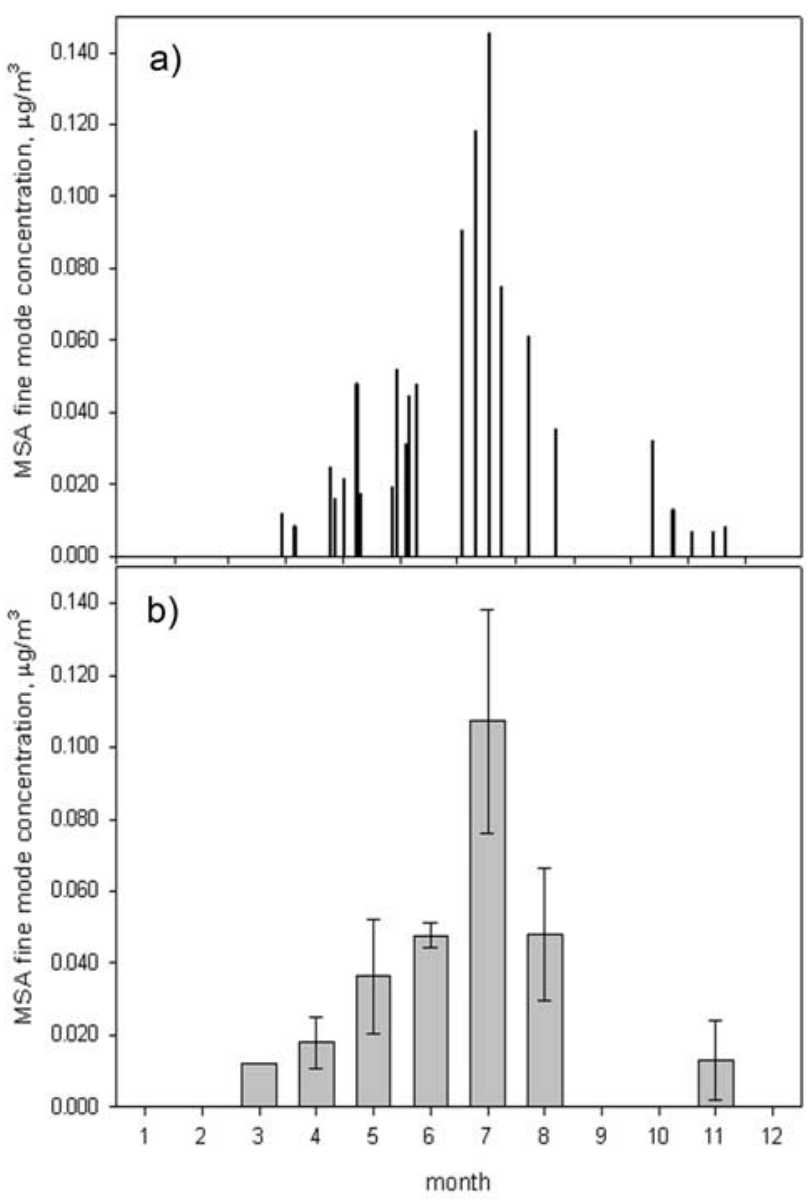

Figure 9. Seasonal variation of the submicron MSA concentration. (a) A time series of individual samples analyzed. (b) Average monthly concentration $\pm 1 \sigma$. Data are presented from January 2002 to June 2004 (month 1 is January). was based on a limited data set. However, Figure 11 reveals occasional low WSOC concentrations during summer. It is considered that low concentrations have been caused by air masses passing over depleted plankton regions of the Atlantic. This finding means that a reduced phytoplankton biomass is present in North Atlantic, and the area rich in phytoplankton biomass has moved toward the north. SeaWiFS chlorophyll- $a$ images show that high biological activity regions fluctuate; that is, every year they move toward the north during summer and move back southward during autumn. Seasonal patterns of WSOC shows that during high biological activity periods, WSOC concentration reaches $0.2 \mu \mathrm{gC} \mathrm{m}^{-3}$, while during winter or low phytoplankton biomass period it is usually below $0.05 \mu \mathrm{gC} \mathrm{m}$.

[30] Total carbon included water soluble organic carbon, water insoluble and elemental carbon (the latter two determined by EGA technique). The temporal variability of submicron total carbon is shown in Figure 11c. Total carbon (TC) seasonal pattern is presented in Figure 11d. The TC concentration pattern resembles that of soluble organic carbon with lowest concentrations during the winter period and elevated concentrations during the spring to autumn period. However, TC has a slightly different pattern during summer. It shows a maximum in spring, with concentrations exceeding $1 \mu \mathrm{gC} \mathrm{m}{ }^{-3}$, a decline in June and an intermediate rise during late summer and autumn with concentrations of about $0.5 \mu \mathrm{gC} \mathrm{m}{ }^{-3}$. It was already shown above that water soluble organic carbon has a bimodal seasonal pattern. Water insoluble organic carbon had a clear maximum in spring (month of May) and consistently elevated concentrations during the rest of the warm period. The percentage of water soluble organic carbon varied between 10 to $50 \%$ of the total carbon with highest percentages recorded during early spring. Although WSOC is not a major component of the organic aerosol, nevertheless the soluble fraction of the organic carbon plays a more important role in aerosol cloud formation processes.

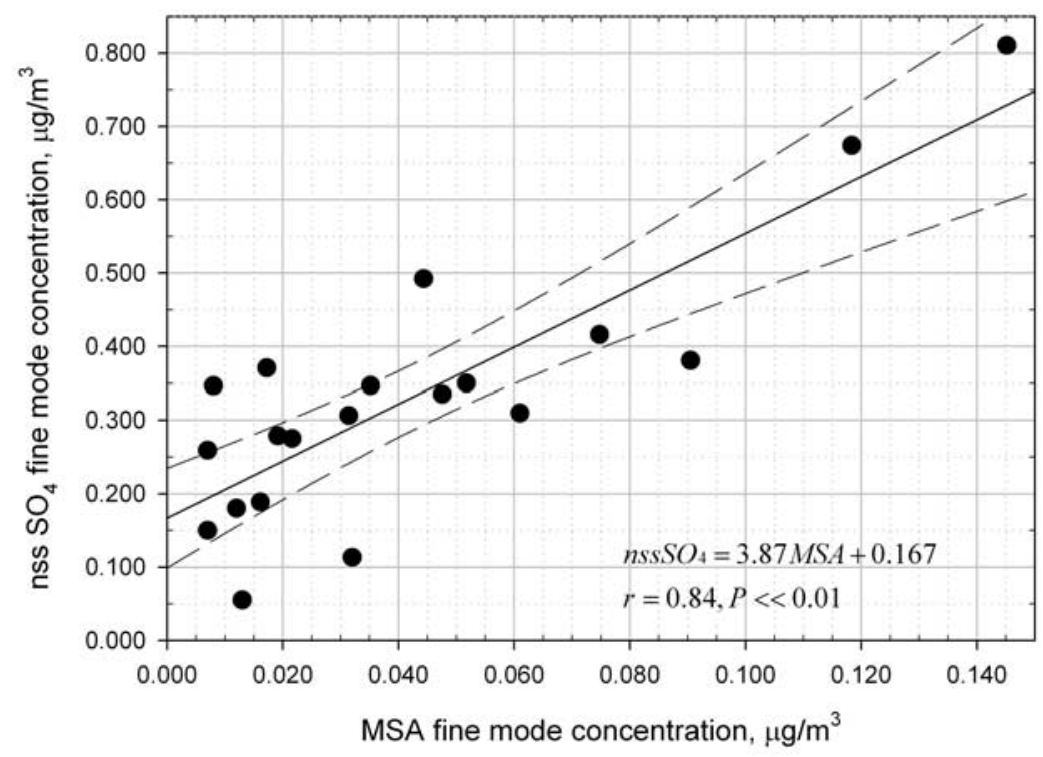

Figure 10. Relationship between nss SO4 fine mode concentration and fine mode MSA concentration. Solid line is regression line. Dashed line is the $99.99 \%$ confidence limit. 

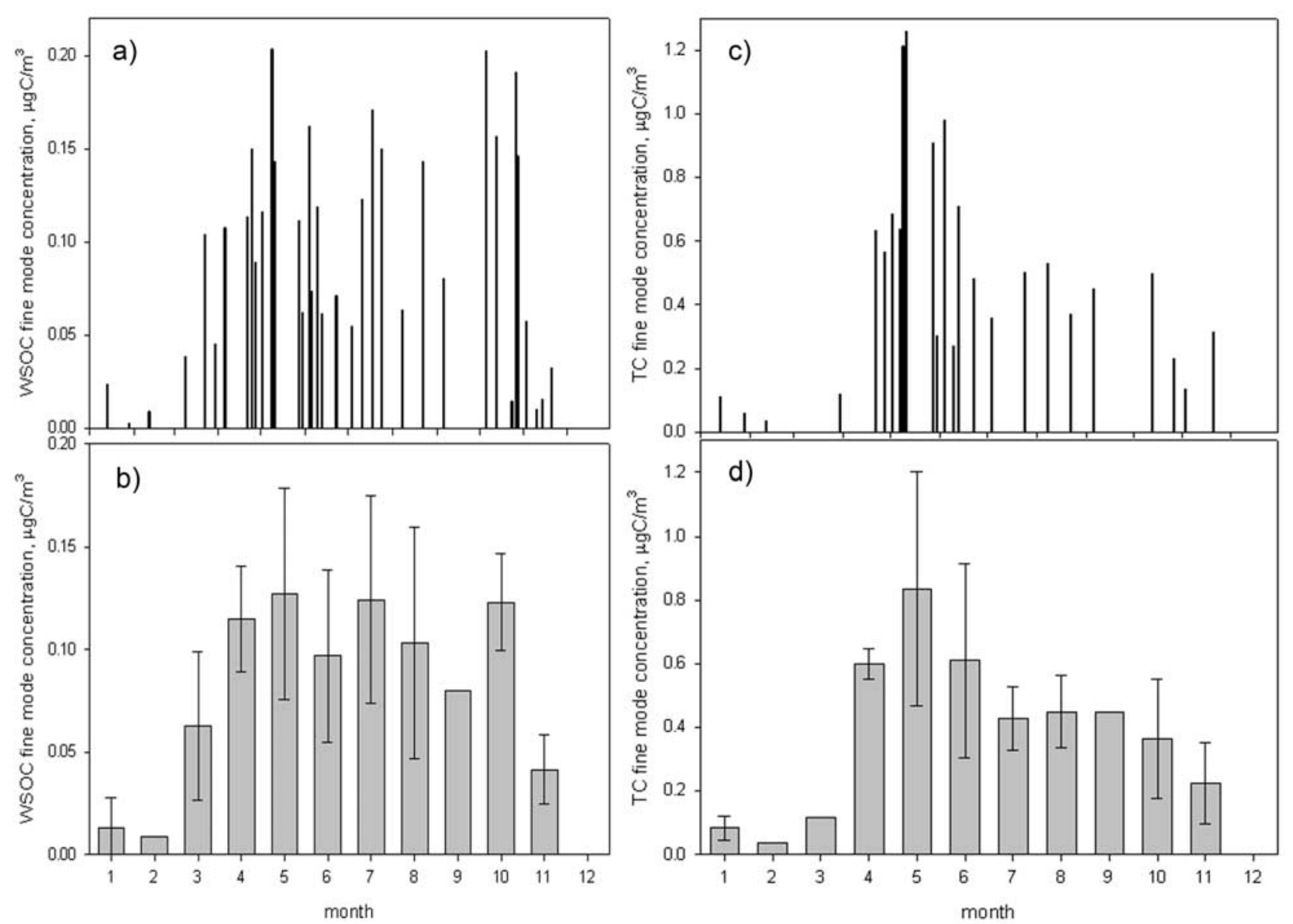

Figure 11. (a) Seasonal variation of the submicron WSOC concentration time series and (b) average monthly concentration $\pm 1 \sigma$ (except for months with a single value). (c) Seasonal variation of submicron $\mathrm{TC}$ concentration time series and (d) average monthly concentration $\pm 1 \sigma$ (except single values).

[31] TC or more specifically water insoluble organic carbon has been traditionally suspected for positive sampling artefacts. Therefore the Hi-vol impactor was fitted with a second backup filter at times in order to get an insight into this problem. The second backup filter showed on average 25 to $30 \%$ of the TC found on the first backup filter, which can be considered as a positive artefact in our samples. However, we did not exclude the potential artefact from TC data, because it likely depends on many factors (temperature, relative humidity, time of year), whose influences have not yet been quantified to a consistent level.

\subsection{Seasonal Scattering Data}

[32] Aerosol light scattering coefficient $\left(\sigma_{\mathrm{sp}}\right)$ at a wavelength of $550 \mathrm{~nm}$ were analyzed and Figure 12 shows monthly averaged values over the same period. A minimum monthly averaged scattering coefficient value of $5.56 \mathrm{Mm}^{-1}$ is found in August and a maximum of $21 \mathrm{Mm}^{-1}$ in February. Wind speed is higher in winter (mean values between 13 to $15 \mathrm{~m} \mathrm{~s}^{-1}$ ) and therefore generates more sea salt. Sea salt is considered to be the largest contributor to the scattering coefficient over the North Atlantic with most of the contribution coming from the supermicron mode
[Kleefeld et al., 2002], and hence the scattering is significantly higher in winter than in summer when wind is much lower (around $5 \mathrm{~m} \mathrm{~s}^{-1}$ ). This also holds for spring and fall (mean wind speed of around 8-9 $\mathrm{m} \mathrm{s}^{-1}$ ) (see Figure 12). Aerosol scattering coefficient carries information on the seasonal contribution of the super micron component of the aerosol size spectra. Because of sampling effects of the community sample duct and the nephelometer inlet system, the estimated cut size for these measurements is of the order of 5 microns and consequently misses the dominant supermicron scattering signal [Kleefeld et al., 2002].

[33] Analysis of the Angström coefficient yields information on the dominant particle size contributing to the scattering signal. Larger values of the Angström coefficient correspond to smaller particle size. A value of less than about 0.5 indicates the presence of coarse mode sea-salt aerosols [Smirnov et al., 2002]. For the data presented here, aerosols sampled during late spring and summer exhibits larger Angström coefficients indicating a large contribution of fine or accumulation mode in the spectra compared to winter data (see Figure 12). In winter, the aerosol properties are always predominantly influenced by the coarse sea-salt mode, whereas in summer and spring the contribution of the 

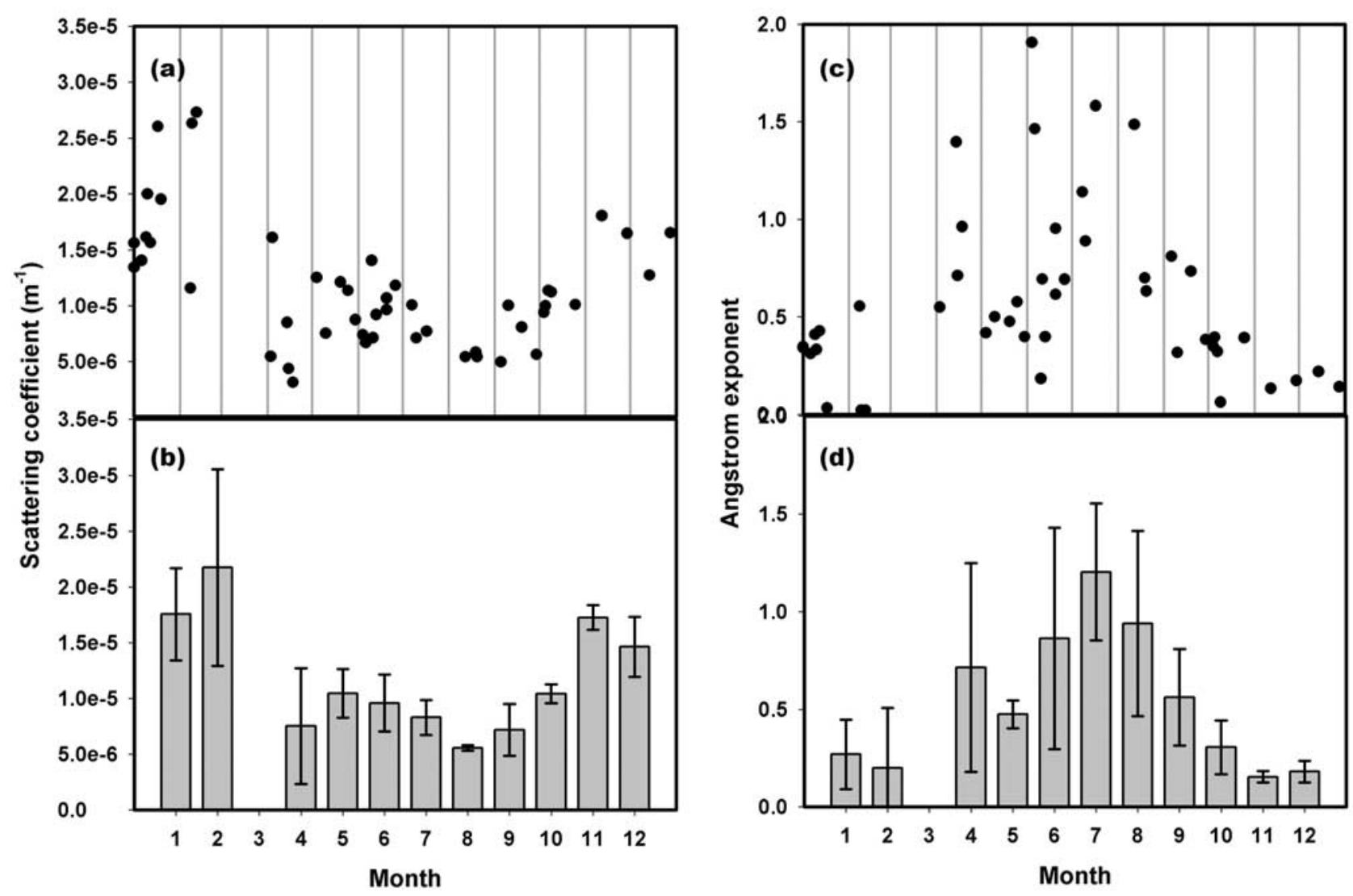

Figure 12. (a) Variation of aerosol scattering coefficient $\left(\mathrm{m}^{-1}\right)$ at a wavelength of $550 \mathrm{~nm}$ measured by the nephelometer for clean air mass cases. (b) Monthly averaged values of aerosol scattering coefficient $\left(\mathrm{m}^{-1}\right)$ at a wavelength of $550 \mathrm{~nm}$. (c) Variation of aerosol Angstrom exponent derived from scattering coefficient measurements (at wavelengths of 450, 550 and $700 \mathrm{~nm}$ ). (d) Monthly averaged values of Angstrom exponent derived from scattering coefficient measurements. All data are for clean air mass cases over the period from January 2002 to June 2004.

fine mode is generally more important than that of the coarse mode.

\section{Discussion}

[34] The results presented above display clear seasonal differences in both the spectral modal properties and the chemical composition suggesting differences in the NE Atlantic marine aerosol formation processes. Both primary and secondary formation processes are likely to contribute to the observed physical and chemical size distributions but it is not clear to what extent each process contributes. Secondary processes such as condensation growth or incloud chemical processing are not thought to be significant since only aerosol size distributions for which modal diameters did not change over a period of at least 12 hours were selected for this analysis. In fact, modal growth as observed at Mace Head under nonmarine conditions [O'Dowd, 2001] or in other marine [O'Dowd et al., 1999] and continental locations [Kulmala et al., 2001] is not observed for the data presented here, suggesting that if secondary aerosol formation processes contributed to the observed properties, either the contribution occurred prior to air masses arriving at Mace Head, or the contribution is minor. There is no reason to think that such secondary formation processes would only be occurring over the open ocean and not in the vicinity of Mace Head, thus we would suggest that secondary particle formation does not dominate the marine aerosol production processes in this region and it appears more likely that primary processes, driven by the variation of wind speed, sea surface temperature and organic matter concentration at the ocean surface are more likely to have the dominant influence on the marine aerosol distribution under the conditions presented since all these factors influence the bubble-mediated aerosol production [Blanchard, 1983].

[35] The main feature observed from the combined physical and chemical aerosol measurements is that, in winter, when biological activity is low, the aerosol properties are characterized by smaller modal diameters and lower organic content, while during spring-summer, when biological activity is high, the aerosol is characterized by larger modal diameters and maximum organic content. In other words, the aerosols with the large organic fraction appear to be physically larger than the aerosols without. Recent laboratory studies into the impact of surfactants on bubblemediated aerosol production by Sellegri et al. [2006] revealed new insights into bubble-mediated aerosol production. Their work focused on the effect of temperature and a synthetic surfactant (sodium dodecyl sulphate) on aerosol 
production in synthetic seawater. Sellegri et al. [2006] found that at a $23^{\circ} \mathrm{C}$, the aerosol distribution resulting from the use of surfactant-free seawater comprised three modes: (1) a dominant accumulation mode at $110 \mathrm{~nm} ;(2)$ an Aitken mode at $45 \mathrm{~nm}$; and (3) a third mode, at $300 \mathrm{~nm}$, resulting from forced bursting of bubbles. The forced bursting occurs when bubbles fail to burst upon reaching the surface and are later shattered by splashing associated with breaking waves and/or wind pressure at the surface. At $4^{\circ} \mathrm{C}$, the accumulation mode diameter was reduced to $85 \mathrm{~nm}$, the Aitken mode diameter was reduced to $<30 \mathrm{~nm}$ and the $300 \mathrm{~nm}$ mode diameter was reduced to $200 \mathrm{~nm}$. With the addition of SDS, the relative importance of the mode resulting from forced bursting increased dramatically.

[36] The laboratory results were compared to the observed seasonality of North Atlantic marine aerosol (as reported here) where a progression from mode diameter minima in winter to maxima in summer is seen. The bimodality and the seasonality in modal diameters could be, to a large extent, explained by a combination of the three modes observed in the laboratory and their variation as a function of sea surface temperature and seawater surfactant concentration; however, it was acknowledged that secondary aerosol formation processes were also required to explain the complete picture, and in particular, the amplitude of the Aitken mode in summer time. Obviously, the nss-sulphate contribution is clearly produced from secondary processes and this accounts for typically to no more than $15 \%$ of the submicron mass, but the fraction of organic matter produced from primary and secondary processes still needs to be resolved.

[37] If one considers that the dominant process influencing marine aerosol processes relates to primary aerosol production, there is an apparent paradox to be resolved: namely, during the period of high biological activity (summer), wind speeds tend to be lower than periods of low biological activity (winter), yet the produced particle sizes tend to be larger, and consequently more submicron aerosol mass is injected into the marine boundary layer. This increase in mass appears mostly as organic matter. Even though the bubble concentration would be expected to be lower for lower mean wind speeds, there is likely to be an increase in the fraction of bubbles stabilized by the presence of surfactants, and consequently an increase in the forced bursting of bubbles which results in an increased flux of larger drops with greater mass. In addition, the presence of surfactants in the surface microlayer could lead to a greater residual aerosol mass as the droplet evaporates since the organics would have displaced some of the droplet water content. Clearly, considerable more work is required to elucidate the impacts of natural surfactants and organic matter at the ocean surface on bubble-mediated aerosol production.

\section{Conclusions}

[38] This study presents seasonal physicochemical characteristics of North Atlantic marine aerosols, from continuous measurements at Mace Head over the period from January 2002 to June 2004. Aerosol (SMPS) microphysical measurements show that typical North Atlantic marine aerosol size distributions have 2 lognormal modes in the submicron size range, namely the Aitken and accumulation modes. The lognormal distribution modal diameters show clear seasonal variations. The seasonally averaged Aitken mode diameter increased from $0.031 \mu \mathrm{m}$ in winter to $0.049 \mu \mathrm{m}$ in summer. The accumulation mode mean diameter also increased from $0.103 \mu \mathrm{m}$ in winter to $0.177 \mu \mathrm{m}$ in summer. The size segregated MOUDI mass spectra also show a mode around $0.4 \mu \mathrm{m}$ during spring-autumn, but this is not seen in the winter samples. The accumulation mode mass from the MOUDI measurements also show a seasonal variation, a minimum during winter and a maximum in summer. This higher mass concentration during the blooming of North Atlantic phytoplankton is attributed to the contribution of organic submicron aerosol produced by the primary bubble bursting process. A supermicron size particle mode was constantly found at $2 \mu \mathrm{m}$ for all seasons showing a $30 \%$ higher concentration on average during winter than summer resulting from higher wind speeds during winter.

[39] Chemical analysis of North Atlantic fine and coarse mode particles showed that the concentration of sea salt has a seasonal pattern, with a minimum in summer and a maximum in winter following the wind speed pattern. (higher in winter, lower in summer). By contrast, the nss sulphate concentration in fine mode particles showed an opposite seasonal pattern with lower values during winter and higher values during midsummer. The seasonal variation of nss sulphate concentration is attributed to the cycle of marine biota which is active during the North Atlantic phytoplankton blooming seasons, generally characterized by two or more peaks from spring to autumn. This marine biota activity also affects the contribution of organic matter in the fine mode particles. Water-soluble organic carbon and total carbon analyzed from the Berner impactor and Hi-vol samples also showed a distinctive seasonal pattern. The fine mode WSOC and TC concentration has higher values during the spring-autumn season and lower values in winter. Some case studies for occasionally relatively lower WSOC concentrations during summer months proved that the strength of marine biota activity can also affect the contribution of organic matter to the total mass of fine particles, as the air mass for those cases were found to originate from relatively lower biologically active areas even in summer time. The fine mode WSOC concentration during the high biological activity period peaked at $0.2 \mu \mathrm{gC} \mathrm{m}{ }^{-3}$, while during winter or low phytoplankton biomass period the value is usually lower than $0.05 \mu \mathrm{gC} \mathrm{m}^{-3}$. The $\mathrm{TC}$ concentration showed a maximum in spring of around $1.2 \mu \mathrm{gC} \mathrm{m}{ }^{-3}$, and a minimum in winter of $0.1 \mu \mathrm{gC} \mathrm{m}^{-3}$.

[40] The seasonality of the aerosol scattering coefficient stems from the physicochemical properties of North Atlantic marine aerosols which is clearly evident. Aerosol light scattering coefficient shows a minimum value of $5.56 \mathrm{Mm}^{-1}$ in August and a maximum of $21 \mathrm{Mm}^{-1}$ in February. This near four-fold seasonal increase in the aerosol scattering coefficients is due to the higher contribution of wind generated sea salt to the supermicron particles in the MBL during North Atlantic winter, as is also seen from the seasonal MOUDI mass data. By contrast, aerosols during late spring and summer exhibit larger Angström coefficients than winter, indicating a large contribution of the fine or accumulation mode in the spectra compared to winter data.

[41] Seasonal variations of North Atlantic marine aerosols presented in this study highlight the importance of the 
relationship between marine aerosol and biological activity. The seasonal variations in the aerosol size modal diameters and contribution of organic matter to the fine mode aerosol mass indicate that primary particle formation plays an important role in the North Atlantic MBL aerosol budget. Angström exponent analysis using scattering data showed that organic originated submicron aerosol contributes significantly to the scattering of solar light during biologically active seasons.

[42] Acknowledgments. This work was supported by (1) the Irish Research Council for Science, Engineering and Technology; (2) the National Programme for Research in Third Level Institutions, Ireland; and (3) the European Commission under contract EVK2-CT2001-00127 (QUEST). Y. J. Yoon also acknowledges support from the Korea Polar Research Institute under project COMPAC(PE06030). R. Danovaro is gratefully acknowledged for the helpful contribution to the discussion of the results. SeaWiFS chlorophyll products were provided by the SeaWiFS project, NASA/Goddard Space Flight Center and ORBIMAGE. The authors acknowledge NOAA Air Resources Laboratory (ARL) for the provision of the HYSPLIT transport and dispersion model and READY website (http://www.arl.noaa.gov/ready.html) used in this publication.

\section{References}

Anderson, T. L., and J. A. Ogren (1998), Determining aerosol radiative properties using the TSI 3563 integrating nephelometer, Aerosol Sci. Technol., 29, 57-69.

Anderson, T. L., et al. (1996), Performance characteristics of a highsensitivity, three-wavelength, total scatter/backscatter nephelometer, J. Atmos. Oceanic Technol., 13, 967-986.

Blanchard, D. C. (1983), The production, distribution and bacterial enrichment of sea-salt aerosol, in Air-Sea Exchange of Gases and Particles, edited by P. S. Liss and W. G. N. Slinn, pp. 407-454, Springer, New York.

Blanchard, D. C., and A. H. Woodcock (1957), Bubble formation and modification in the sea and its meteorological significance, Tellus, 9, 145-158.

Bodhaine, B. A., N. C. Ahlquist, and R. C. Schnell (1991), 3-wavelength nephelometer suitable for aircraft measurement of background aerosol scattering coefficient, Atmos. Environ., 25, 2267-2276.

Cavalli, F., et al. (2004), Advances in characterization of size-resolved organic matter in marine aerosol over the North Atlantic, J. Geophys. Res., 109, D24215, doi:10.1029/2004JD005137.

Charlson, R. J., J. E. Lovelock, M. O. Andreae, and S. G. Warren (1987), Oceanic phytoplankton, atmospheric sulfur, cloud albedo and climate, Nature, 326, 655-661.

Charlson, R. J., S. E. Schwartz, J. M. Hales, R. D. Cess, J. A. Coakley, J. E. Hansen, and D. J. Hofmann (1992), Climate forcing by anthropogenic aerosols, Science, 255, 423-430.

Cooke, W. F., S. G. Jennings, and T. G. Spain (1997), Black carbon measurements at Mace Head, 1989-1996, J. Geophys. Res., 102, 25,339-25,346.

Fitzgerald, J. W. (1991), Marine aerosols -A review, Atmos. Environ., 25, $533-545$.

Heintzenberg, J., and R. J. Charlson (1996), Design and applications of the integrating nephelometer: A review, J. Atmos. Oceanic Technol., 13, 987-1000.

Hoppel, W. A., J. W. Fitzgerald, G. M. Frick, S. M. Larson, and E. J. Mack (1989), Atmospheric aerosol size distribution and optical properties in the marine boundary layer over the Atlantic Ocean, NRL Rep. 9188, Naval Res. Lab., Washington, D. C.

Houghton, J. T., , Y. Ding, D. J. Griggs, M. Noguer, P. J. van der Winden, and X. Dai (Eds.) (2001), Climate Change 2001: The Scientific Basis. Contribution of Working Group 1 to the Third Assessment Report, 944 pp., Cambridge Univ. Press, New York.

Howell, S., A. A. P. Pszenny, P. Quinn, and B. Huebert (1998), A field intercomparison of three cascade impactors, Aerosol Sci. Technol., 29, $475-492$.

Jennings, S. G., C. Kleefeld, C. D. O’Dowd, C. Junker, T. G. Spain, P. O'Brien, A. F. Roddy, and C. O'Connor (2003), Mace Head atmospheric research station characterization of aerosol radiative parameters, Boreal Environ. Res., 8, 303-314.

Jokinen, V., and J. M. Makela (1997), Closed-loop arrangement with critical orifice for DMA sheath excess flow system, J. Aerosol Sci., 28, 643-648.

Kleefeld, C., C. D. O’Dowd, S. O'Reilly, S. G. Jennings, P. Aalto, E. Becker, G. Kunz, and G. de Leeuw (2002), Relative contribution of submicron and supermicron particles to aerosol light scattering in the marine boundary layer, J. Geophys. Res., 107(D19), 8103, doi:10.1029/ 2000JD000262.
Kulmala, M., et al. (2001), Overview of the international project on biogenic aerosol formation in the boreal forest (BIOFOR), Tellus, Ser. B, 53 , $324-343$.

Matta, E., M. C. Facchini, S. Decesari, M. Mircea, F. Cavalli, S. Fuzzi, J. P. Putaud, and A. Dell'Acqua (2003), Mass closure on the chemical species in size-segregated atmospheric aerosol collected in an urban area of the Po Valley, Italy, Atmos. Chem. Phys., 3, 623-637.

Murphy, D. M., J. R. Anderson, P. K. Quinn, L. M. McInnes, F. J. Brechtel, S. M. Kreidenweis, A. M. Middlebrook, M. Posfai, D. S. Thomson, and P. R. Buseck (1998), Influence of sea-salt on aerosol radiative properties in the Southern Ocean marine boundary layer, Nature, 392, 62-65.

O'Dowd, C. D. (2001), Biogenic coastal aerosol production and its influence on aerosol radiative properties, J. Geophys. Res., 106, 1545-1550.

O'Dowd, C. D., M. H. Smith, and S. G. Jennings (1993), Submicron particle, radon, and soot carbon characteristics over the northeast Atlantic, J. Geophys. Res., 98, 1123-1135.

O’Dowd, C. D., M. H. Smith, I. E. Consterdine, and J. A. Lowe (1997), Marine aerosol, sea-salt, and the marine sulphur cycle: A short review, Atmos. Environ., 31, 73-80.

O’Dowd, C. D., J. A. Lowe, and M. H. Smith (1999), Observations and modelling of aerosol growth in marine stratocumulus-Case study, Atmos. Environ., 33, 3053-3062.

O'Dowd, C. D., et al. (2002a), A dedicated study of New Particle Formation and Fate in the Coastal Environment (PARFORCE): Overview of objectives and achievements, J. Geophys. Res., 107(D19), 8108, doi:10.1029/2001JD000555.

O’Dowd, C. D., et al. (2002b), Coastal new particle formation: Environmental conditions and aerosol physicochemical characteristics during nucleation bursts, J. Geophys. Res., 107(D19), 8107, doi:10.1029/ 2000JD000206.

O’Dowd, C. D., M. C. Facchini, F. Cavalli, D. Ceburnis, M. Mircea, S. Decesari, S. Fuzzi, Y. J. Yoon, and J. P. Putaud (2004), Biogenically driven organic contribution to marine aerosol, Nature, 431, 676-680.

Ogren, J. A. (1995), A systematic approach to in situ observations of aerosol properties, in Aerosol Forcing of Climate, Report of the Dahlem Workshop Berlin, April 24-29, 1994, edited by R. J. Charlson and J. Heintzenberg, 215-226, John Wiley, Hoboken, N. J.

Öström, E., and K. J. Noone (2000), Vertical profiles of aerosol scattering and absorption measured in situ during the North Atlantic Aerosol Characterization Experiment (ACE-2), Tellus, Ser. B, 52, 526-545.

Putaud, J. P., et al. (2000), Chemical mass closure and assessment of the origin of the submicron aerosol in the marine boundary layer and the free troposphere at Tenerife during ACE-2, Tellus, Ser. B., 52, 141-168.

Savoie, D. L., R. Arimoto, W. C. Keene, J. M. Prospero, R. A. Duce, and J. N. Galloway (2002), Marine biogenic and anthropogenic contributions to non-sea-salt sulphate in the marine boundary layer over the North Atlantic Ocean, J. Geophys. Res., 107(D18), 4356, doi:10.1029/ 2001JD000970.

Sellegri, K., C. D. O’Dowd, Y. J. Yoon, S. G. Jennings, and G. de Leeuw (2006), Surfactants and submicron sea spray generation, J. Geophys. Res., 111, D22215, doi:10.1029/2005JD006658.

Smirnov, A., B. N. Holben, Y. J. Kaufman, O. Dubovik, T. F. Eck, I. Slutsker, C. Pietras, and R. N. Halthore (2002), Optical properties of atmospheric aerosol in maritime environments, J. Atmos. Sci., 59, 501-523.

Twomey, S. (1974), Pollution and planetary albedo, Atmos. Environ., 8, $1251-1256$.

Yin, F., D. Grosjean, and J. H. Seinfeld (1990a), Photooxidation of dimethyl sulfide and dimethyl disulfide. I: Mechanism development, J. Atmos. Chem., 11, 309-364.

Yin, F., D. Grosjean, R. C. Flagan, and J. H. Seinfeld (1990b), Photooxidation of dimethyl sulfide and dimethyl disulfide. II: Mechanism evaluation, J. Atmos. Chem., 11, 365-399.

Yoon, Y. J., C. D. O’Dowd, S. G. Jennings, and S. H. Lee (2006), Statistical characteristics and predictability of particle formation events at Mace Head, J. Geophys. Res., 111, D13204, doi:10.1029/2005JD006284.

F. Cavalli, S. Decesari, M. C. Facchini, and S. Fuzzi, Istituto di Scienze dell'Atmosfera e del Clima, Consiglio Nazionale delle Ricerche, I-40129 Bologna, Italy.

D. Ceburnis, S. G. Jennings, and C. D. O'Dowd, Department of Experimental Physics and Environmental Change Institute, National University of Ireland, Galway, Ireland. (colin.odowd@cmas.demon.co.uk)

O. Jourdan and K. Sellegri, Laboratoire de Météorologie Physique, Université Blaise Pascal/Centre National de la Recherche Scientifique, 24, av. des Landais, F-63170 Aubiere, France.

J. P. Putaud, Environment Institute, Joint Research Centre, European Commission, I-21020 Ispra, Italy.

Y. J. Yoon, Korea Polar Research Institute, Korea Ocean Research and Development Institute, Ansan P.O. Box 29, Seoul 425-600, South Korea. 